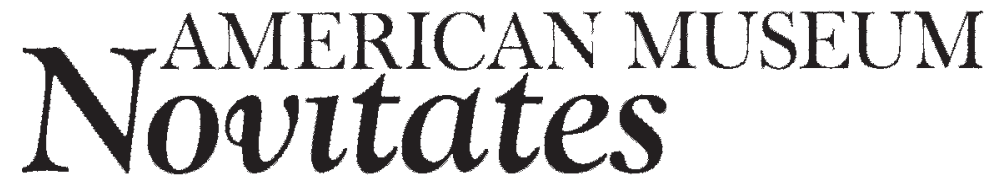

PUBLISHED BY THE AMERICAN MUSEUM OF NATURAL HISTORY CENTRAL PARK WEST AT 79TH STREET, NEW YORK, NY 10024 Number 3572, 39 pp., 14 figures, 4 tables

May 16, 2007

\title{
How Time Flies for Flies: Diverse Diptera from the Triassic of Virginia and Early Radiation of the Order
}

\author{
VLADIMIR BLAGODEROV, ${ }^{1}$ DAVID A. GRIMALDI, ${ }^{2}$ AND \\ NICHOLAS C. FRASER ${ }^{3}$
}

\begin{abstract}
The most diverse and best-preserved early fauna of flies (order Diptera) is described from the Late Carnian (Late Triassic, ca. $220 \mathrm{Ma}$ ) of Virginia, USA. Complete flies are preserved as aluminosilicate films on very fine-grained shales from the Cow Branch Formation, which is part of the Newark Supergroup of Early Mesozoic rift basins from eastern North America. The dipteran fauna consists of eight families (one new), 11 genera (five new), and 16 species (11 new), and includes the following taxa (Blagoderov and Grimaldi are the authors of all new names): Architipula youngi Krzemiński, Metarchilimonia krzeminskorum n.gen., n.sp., and M. solita n.sp. (Limoniidae); Triassopsychoda olseni n.gen., n.sp. (Psychodidae); Culicomorpha indet.; Yalea argentata (Krzemiński), Y. rectimedia n.sp., Alinka cara Krzemiński (Procramptonomyiidae); Veriplecia rugosa n.sp., Virginiptera certa n.gen., n.sp., V. similis n.sp., V. lativentra n.sp. (Paraxymyiidae); Brachyrhyphus distortus n.gen. n.sp. (Protorhyphidae); ?Crosaphis virginiensis n.sp. (Crosaphididae); and Prosechamyia trimedia n.gen., n.sp., P. dimedia n.sp. (Prosechamyiidae, new family). Particularly significant is a culicomorphan with a long proboscis, which is the earliest fossil record of a structure specialized apparently for blood feeding. Also, Prosechamyia appears to be a stem group to the very diverse infraorder Brachycera, the earliest definitive members of which appear in the Early Jurassic. Phylogenetic relationships of major clades of living and extinct nematocerous Diptera are analyzed, indicating that infraordinal-level diversification was complete by the Late Triassic. Flies did not reach modern levels of ecological abundance until the midJurassic, apparently due to diversification within most infraorders by that time.
\end{abstract}

\footnotetext{
${ }^{1}$ Division of Invertebrate Zoology (Entomology), American Museum of Natural History; presently: Department of Entomology, The Natural History Museum, Cromwell Road, London UK.

${ }^{2}$ Division of Invertebrate Zoology (Entomology), American Museum of Natural History (grimaldi@amnh.org).

${ }^{3}$ Virginia Museum of Natural History, 1001 Douglas Avenue, Martinsville, VA 24112 (nfraser@vmnh.net).
} 


\section{INTRODUCTION}

The Diptera, or true flies, comprise one of the oldest lineages of holometabolous insects, with the earliest definitive flies known from the mid-Triassic of France, approximately 230 Ma (Krzemiński and Krzemińska, 2003; Krzemiński et al., 1994). Since the Triassic, flies have evolved into one of the most diverse orders of living insects, with approximately 120,000 described species, and estimates place the actual numbers near one million or more (Gaston, 1991). Ecologically, flies are arguably the most diverse of all orders of insects, including species that are vertebrate ectoparasites, arthropod parasitoids, phytophages, pollenivores, predators, and, of course, saprophages (Grimaldi and Engel, 2005). In this study we make a substantial contribution to knowledge of the evolutionary history of the Diptera by describing the most diverse diperan fauna now known from the Triassic.

Relationships among the major clades, or infraorders, of Diptera is not settled (Hennig, 1973; Oosterbroek and Courtney, 1995; Wood and Borkent, 1989), which is due in part to vague concepts for some of the infraorders, such as Psychodomorpha and Bibionomorpha. Vague infraordinal concepts themselves may be a result of morphological work that is insufficient to date or in its entirety. This is doubtful, though, since the basal relationships of all other major holometabolous orders have been well resolved using morphological characters (Grimaldi and Engel, 2005), and there is no reason to believe Diptera should be any different. Unlike the other holometabolous orders, though, basal relationships of Diptera have not been examined using DNA sequences. If indeed the morphology of Recent Diptera is insufficient to resolve basal relationships, it is possible that early fossils could possess intermediate features that better reveal homologies, such as is the case with Tanyderidae and Psychodidae (Ansorge, 1994) and Valeseguyidae and Scatopsoidea (Amorim and Grimaldi, 2006). In taxa with extensive extinction of stem groups, obscure relationships among crown groups would be expected. Alternatively, relationships among crown groups can also be obscured if they diverged very close in time or simultaneously.
EARly Fossil ReCORD: The earliest and closest known relatives of flies appeared in the Permian. These include Permotipula particia Tillyard, 1929 and Robinjohnia tillyardi Martynova, 1948, from the Late Permian (Tatarian: $255 \mathrm{Ma}$ ) of Belmont and Warner's Bay, New South Wales, Australia (Willmann 1989a, b; Shcherbakov et al., 1995). Also related to Diptera, but more distantly, are the extinct families Liassophilidae (Triassic to mid-Jurassic of Eurasia) and the Permotanyderidae (Permian of Australia). Permotipula is known only from a single wing; specimens of the other groups were four-winged insects, though the hind wings of Liassophilidae were reduced in size. Deposits of insects from the Early Triassic are very rare (reviewed in Rasnitsyn and Quicke, 2002), and so there are no Diptera known from this period. In the mid- to Late Triassic, though, some 230$210 \mathrm{Ma}$, a sudden diversity of true (i.e., twowinged) Diptera occurred, representing all but one of the six living infraorders, 14 families (all but one extinct), and 28 species, not including the present study (table 1). Triassic Diptera are known from seven deposits in Asia, Australia, Europe, and North America (reviewed by Krzemiński 1992; Krzemiński and Evenhuis, 2000; Krzemiński and Krzemińska, 2003; Shcherbakov et al., 1995, fig. 4). ${ }^{4}$ To date, no Diptera are known from the insect-bearing Triassic deposits in Argentina (Martins-Neto, 2003), and only one is known from the prolific Molteno Formation of South Africa (Anderson and Anderson, 1993), which is of indeterminate identity (Blagoderov and Grimaldi, unpubl.).

The Virginia Triassic: All of the Diptera specimens based on the current study are from the quarries of the Solite Corporation in Cascade, Virginia (hereafter, the "Solite quarries") on the border of Virginia and North Carolina. These quarries lie in the Danville-

\footnotetext{
${ }^{4}$ Triassochoristites jinsuoguanensis (Hong and Guo 2003) was recently described in the Mesopanorpodidae (Mecopterida) but probably belongs to the dipteran family Vladipteridae. This conclusion is based on the structure of the cubital complex, with a convex $\mathrm{CuA}$ and associated concave $i C u$ vein, a distinct kink at the base of the radius, three long $\left(\mathrm{R}_{3}-\mathrm{R}_{5}\right)$ veins and a short, oblique vein $\mathrm{R}_{2}$ in the radial sector (this last vein was misinterpreted on the drawing, but is clearly seen on the published photograph). These are all apomorphies of Diptera.
} 


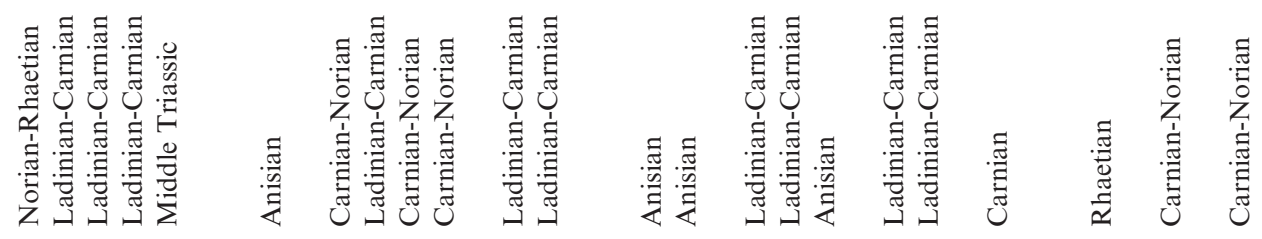

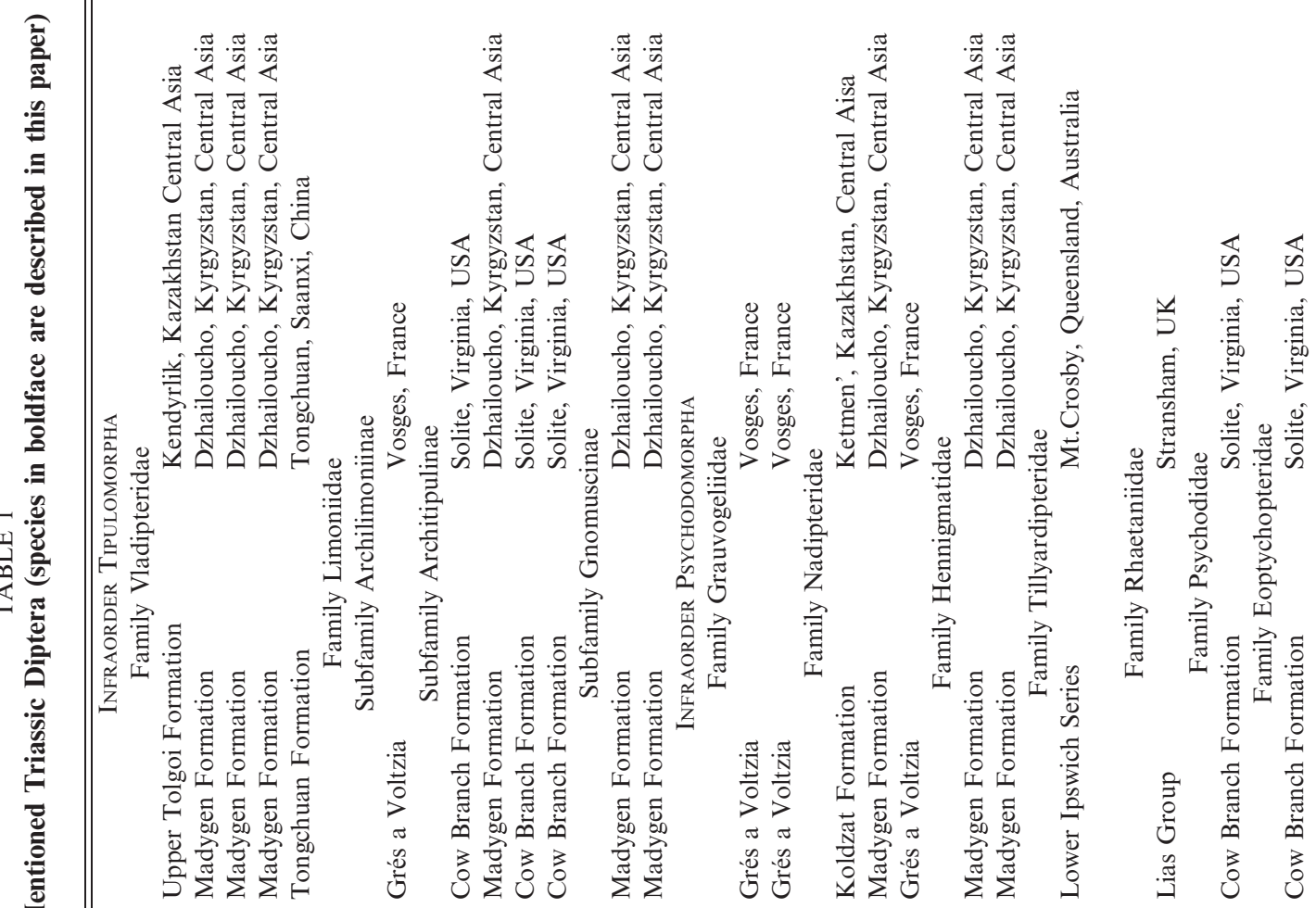
骂

高

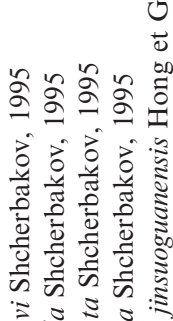

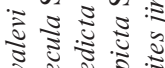

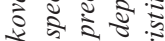

굴.

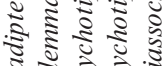

उ.

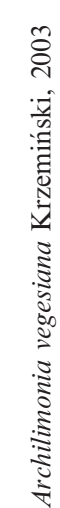

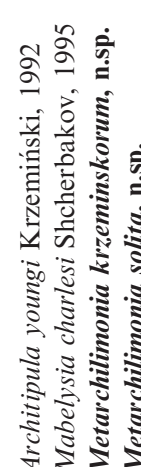

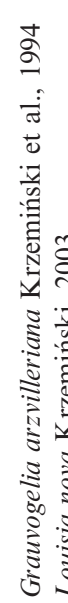

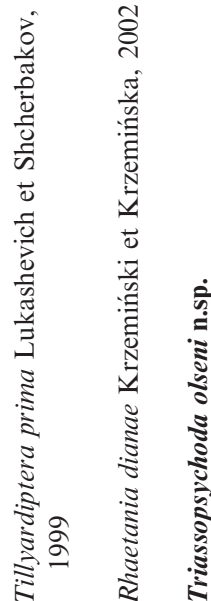

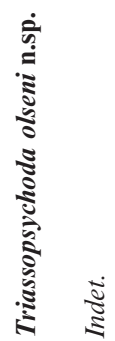




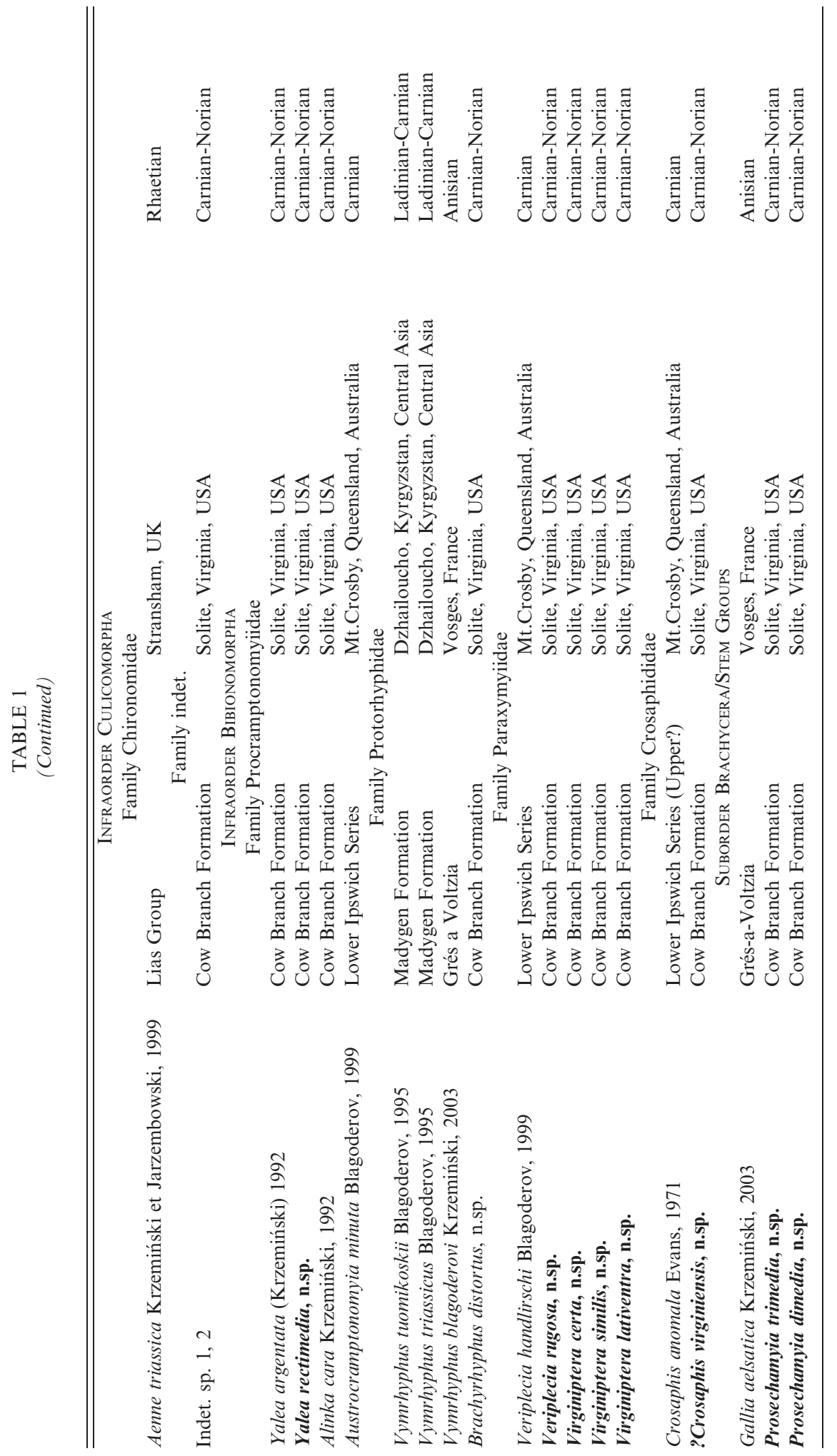




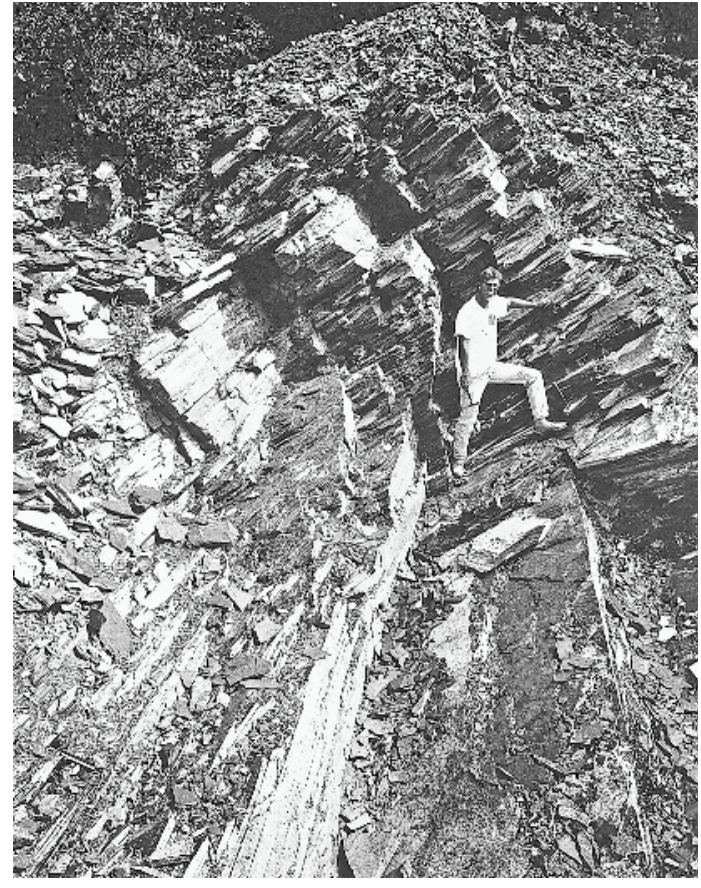

Fig. 1. Nick Fraser standing on an excavated section of the insect layer in the Cow Branch Formation from the Solite Quarry. The layer is a fine-grained black shale that dips northeast at $34^{\circ}$.

Dan River Jurassic-Triassic rift lake basin of the Eastern U.S. (LeTourneau and Olsen, 2003). Fossil insects from this deposit were first reported by Olsen et al. (1978), then by Fraser et al. (1996) based on abundant new material. Olsen's material is housed in the Peabody Museum of Natural History at Yale University, New Haven, CT (hereafter, "YPM"), and all other specimens are housed in the Virginia Museum of Natural History, Martinsville, VA (hereafter, "VMNH"). In the quarries there are outcrops of the upper part of the Carnian-aged (ca. 235-223 Ma) Cow Branch Formation (figs. 1, 2). This formation originated in one of a series of rift basin lakes created during the formation of Pangaea. Some of these ancient lakes reveal striking 21,000-year periods in sedimentation, caused by Van Houten cycles (Olsen, 1986; Witte et al., 1991). Van Houten cycles are cyclical changes in precipitation caused by Milankovitch-type orbitally driven changes in solar insolation (Olsen, 1986), whose periodicitiy is affected by the 21,000-year cycles in the precession of the equinoxes. Over 30 Van Houten cycles are preserved in the two main Solite quarries, and one cycle has proven to be particularly fossiliferous, including many insects (fig. 2).

The richest strata in the Solite quarries contain insects and the best-preserved plants and vertebrates, which also have the least bioturbation and the finest microlamination. Beard et al. (submitted) suggest the insect layer may reflect an environment in transition from ephemeral lake or bacterially matted lake margin to standing water marked by periodic carbonate precipitation. High $\mathrm{CO}_{2}$ in the lake sediment may have rendered it toxic to scavengers and other benthic organisms, either directly or by promoting the growth of toxic algae. A modern analog may be the saline, alkaline dolomite lakes of South Australia. Insects are found in very finegrained, black shales, preserved entirely as two-dimensional, silvery films composed of aluminosilicates with essentially no relief. Preservation of the insects is of microscopic scale, including microtrichia about $1 \mu \mathrm{m}$ in thickness. The insects are preserved with a significant diversity of vascular land plants, including ferns, ginkgophytes, cycads, and abundant conifers and Bennettitales, which appear to be close relatives of conifers (Fraser et al., 1996; Axsmith et al., 1997). Insect diversity includes at least 11 orders of pterygote insects: Blattodea, Coleoptera, Diptera, Mecopterida, Odonata, Orthoptera, Plecoptera, Sternorrhyncha, Auchenorrhyncha, Heteroptera, and Thysanoptera, comprising perhaps 50 species known thus far (Fraser and Grimaldi, 1999, 2003). The Cow Branch Formation is the only significant deposit of Triassic insects from North America, and contains taxa that are among the oldest known records of Thysanoptera (Grimaldi et al., 2004), and certain families in several orders (e.g., Belostomatidae [Heteroptera], Staphylinidae [Coleoptera]).

The suggestion that the Cow Branch Formation "may be younger than judged from paleobotanical data" (Shcherbakov et al., 1995: 78) has little foundation, since the stratigraphy of the formation is well documented and correlated with other Late Triassic and Early Jurassic deposits of the 


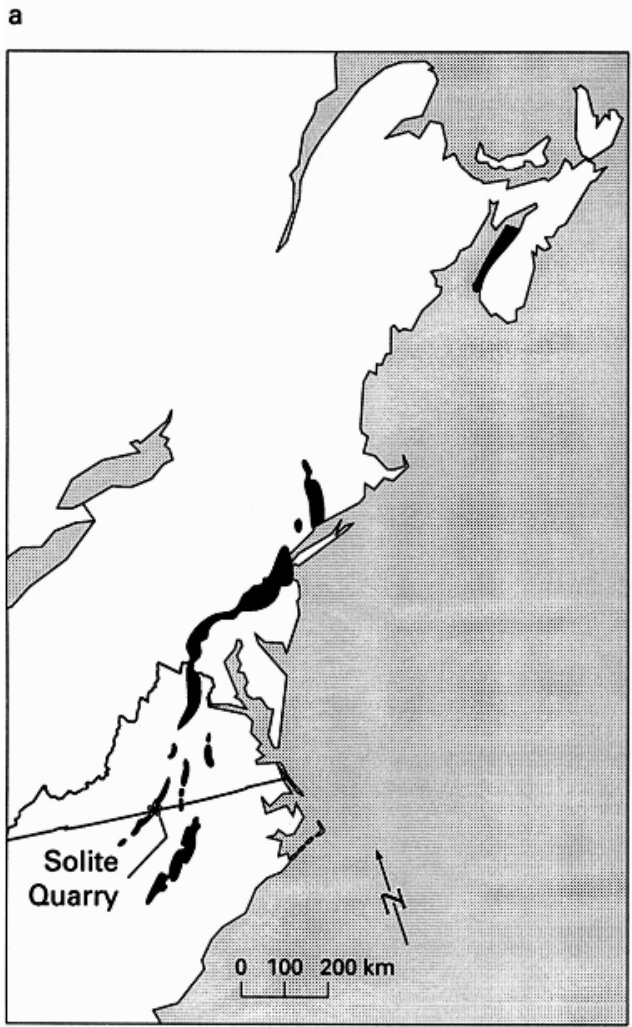

b
(cm)

$$
0
$$
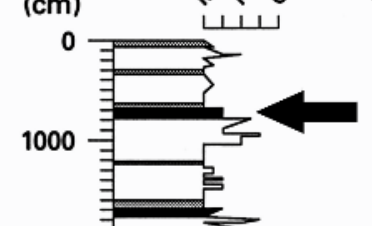

2000

3000

4000

5000

6000

7000

8000

9000

00

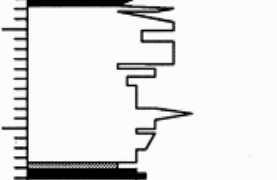

-

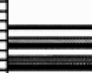

0

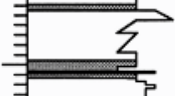

00

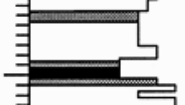

10000

11000

12000

13000

140

1500

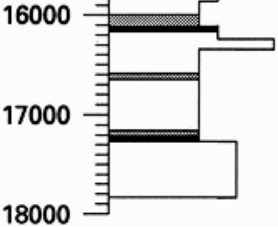

Depth

rank

012345

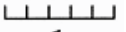
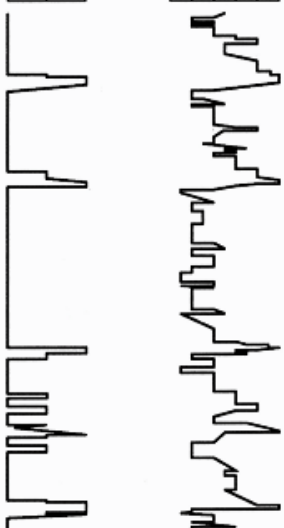

2
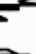

$\frac{5}{5}$

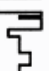

3
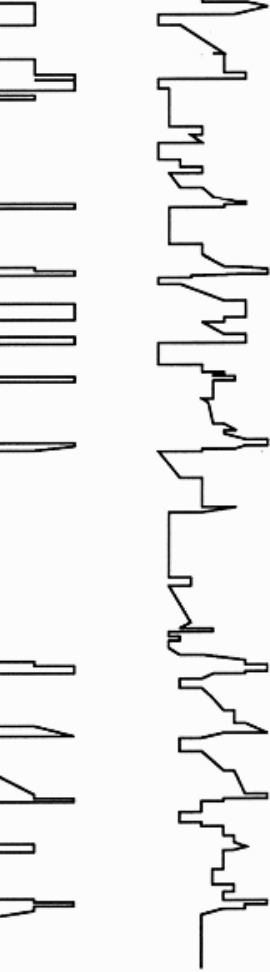

Fig. 2. Map and stratigraphy of the Triassic-Jurassic Newark Basin deposits. a. Map showing location of deposits, and of the Solite quarries. b. Stratigraphic sequence, with an arrow indicating the insect layer. 
eastern North American rift valleys and with the Chinle Formation of the southwestern U.S., including the use of paleomagnetic dating (Olsen et al., 1978; Kent et al., 1995). The vertebrates in the assemblage also correlate with Carnian-aged vertebrates (Lucas and Huber, 2003), including the abundant amphibious protosaurian reptile Tanytrachelos. The age of the formation is Late Carnian, about 220 Ma.

\section{MATERIALS AND METHODS}

Perhaps the most significant feature of the Virginia Triassic deposits is their preservation. Where most other Triassic flies are known only as isolated and dissociated wings, the Virginia Triassic flies are mostly completely articulated. Having features of the legs (e.g., size of coxae, presence and size of tibial spurs) and head (e.g., structure of antennae) greatly improves phylogenetic inference. Proper study of the insects from the Solite quarries, however, requires wetting of the rock surface to improve contrast and an intense but diffuse light source. Specimens were wet with an evaporative solvent, generally $70 \%$ ethanol, then carefully blotted dry after study using a soft tissue. A fiberoptic ring light is absolutely necessary to illuminate the dim silvery images; directional light from fiber optic light guides do not adequately reveal details. Photography was done by attaching a ring light to a $1000 \mathrm{~W}$ output fiberoptic flash unit (MicrOptics, Inc.: ML-1000), and photographing with an Infinity K-2 long distance microscope and a Nikon D-1 digital camera (see www.microptics-usa.com). Wetted specimens were illustrated using a drawing tube attached to a stereoscope using ring-light illumination; use of polarizing film also helps.

\section{SYSTEMATICS}

\section{INFRAORDER TIPULOMORPHA}

Known as crane flies, the infraorder includes about 15,000 species in four living families: Tipulidae, Limoniidae, Cylindrotomidae, and Trichoceridae (the latter is sometimes placed near Psychodidae based on larval morphology). The Triassic family
Vladipteridae, which has the most generalized venation among Diptera, also belongs here. Larvae of tipulomorphs are aquatic, semiaquatic or terrestrial, but usually associated with moist habitats, often found in decomposing plant material.

\section{FAMILY LIMONIIDAE RONDANI, 1856}

This is one of the largest families of Diptera with more than 11,000 Recent and 300 fossil species described (Evenhuis, 1994). The majority of Mesozoic limoniids belong to the basal subfamily Architipulinae Handlirsch.

\section{Architipula youngi Krzemiński, 1992 figures $3 \mathrm{a}, 8 \mathrm{a}$}

Architipula youngi Krzemiński, 1992: 43.

In addition to the description of Krzemiński (1992) a faint pterostigma is observed at the apex of $R_{1}$ and $R_{2}$. Krzemiński indicated holotype collection number as 1103 , but actually the specimen is registered under number YPM 35968. Three other paratypes are very poorly preserved. Specimen YPM 30077 can be identified as Tipulomorpha incertae sedis; specimen YPM 35973 (indicated as \# 100000) is not conspecific with Architipula youngi since the fork $\mathrm{R}_{2+3}$ and $\mathrm{R}_{4}$ is shorter than it's stem; specimen YPM 35969 lacks wings and could belong to Culicomorpha or Bibionomorpha as well as Tipulomorpha.

\section{Metarchilimonia Blagoderov and Grimaldi, new genus}

Diagnosis: Small tipuloids with relatively wide wings; Sc short, approximately $1 / 2$ the wing length. $R_{2}$ meets $R_{1} \cdot R_{4}$ forms a stalk with $\mathrm{R}_{5}, r-m$ connects $\mathrm{M}_{1+2}$ and $\mathrm{R}_{5}$. Crossvein $m-c u$ connected to the base of fork of $\mathrm{M}_{3+4}$.

TyPE SPeCIEs: Metarchilimonia krzeminskorum n.gen., n.sp.

Discussion: The new genus is close to Archilimonia Krzemiński and Krzemińska, 2003 , by virtue of a short Sc, a similar system of vein forks, $m$-cu close to the base of the fork of $\mathrm{M}_{3+4}$. Mabelisia Shcherbakov and Gnomusca Shcherbakov, both from the Madygen Formation in Kyrgyzstan, also have 

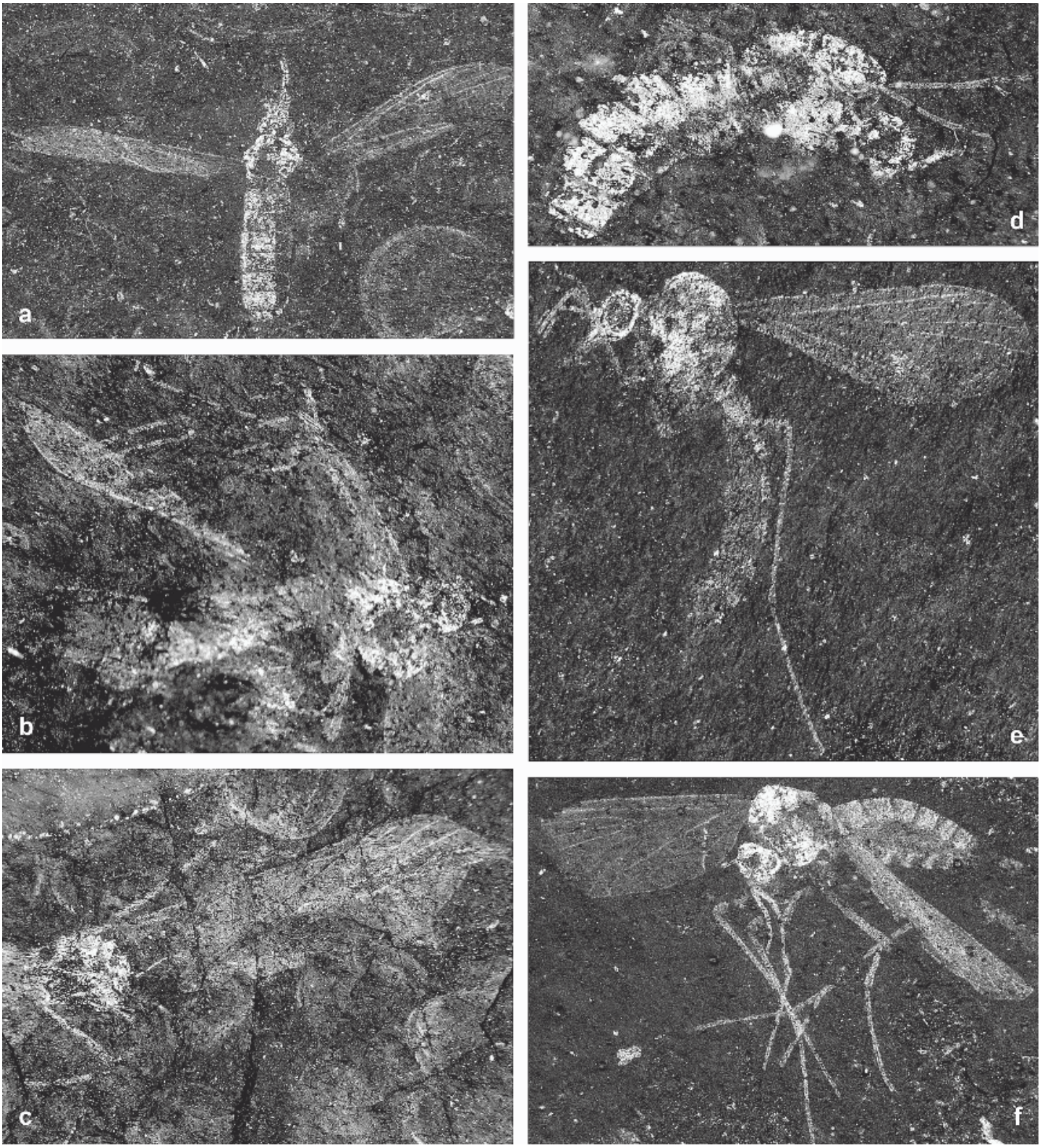

Fig. 3. Photomicrographs of tipulomorphan Diptera from the Late Triassic of the Cow Branch Formation, Solite Quarry. a. Architipula youngi Krzemiński, YPM 35986. b. Tipulomorpha indet., YPM 30077. c. Tipulomorpha indet., YPM 35973. d. Diptera indet., YPM 35969. e. Metarchilimonia krzeminskorum Blagoderov and Grimaldi, holotype VMNH 732. f. Metarchilimonia krzeminskorum Blagoderov and Grimaldi, paratype VMNH 3671. For size scales see fig. 8.

vein Sc rather short and have a similar structure of RS (at least in G. renixa), but they are significantly different in many other aspects of venation. Metarchilimonia differs from Architipula youngi Krzemiński, also from the Solite quarries, by the former having a wider wing, more proximal position of $\mathrm{R}_{2}$, more distal position of $r-m$ with respect to discal cell and the forking pattern of the radial veins. 
ETYMOLOGY: From the Greek word $\mu \varepsilon \tau$, meaning "after" or "next to", and Archilimonia. The name is feminine.

\section{Metarchilimonia krzeminskorum}

Blagoderov and Grimaldi, new species figures $3 \mathrm{e}, \mathrm{f}, 8 \mathrm{c}, \mathrm{d}$

DiAgNosis: $\mathrm{Sc}_{2}$ preapical, discal cell shorter than fork of $\mathbf{M}_{1+2}$.

DESCRIPTION: Female. Measurements: body length $4.7 \mathrm{~mm}$, wing length $3.2 \mathrm{~mm}$. Head round, antennae with 14 flagellomeres, gradually tapered in width toward apex. Scape short, smaller than basal flagellomere. Mouthparts forming rostrum, approximately $1.3 \times$ greatest length of eye; palpi short (segmentation not preserved). Scutum arched. Wing moderately wide, width $0.39 \times$ the length. Sc short, $0.53 \times$ the wing length, ends slightly proximal to level of base of $\mathrm{R}_{2+3}$ stem. $\mathrm{Sc}_{2}$ present, preapical. Base of stem of $\mathrm{RS}$ at $0.37 \times$ the wing length. Five branches of RS, four reaching wing margin. $R_{2}$ meeting $R_{1}$ near wing margin. Stem of $R_{2+3}$ parallel to $R_{1}$, slightly bent at base. $R_{4+5}$ very short, $0.5 \times$ the length of section of $\mathrm{R}_{5}$ anterior to $r-m$. Base of $\mathrm{R}_{5}$ transverse. Length of $\mathrm{R}_{5}$ nearly $2 \times$ longer than stem of RS. Basal fork of $M$ at level of Sc apex. $\mathrm{M}_{3}$ connected to $\mathrm{M}_{1+2}$ near the middle of stem of latter. Anterior margin of discal cell $1.3 \times$ longer than stem of $\mathrm{M}_{1+2}$ and $0.8 \times$ the length of $\mathrm{M}_{1}$. Posterior margin of discal cell $0.7 \times$ length of $\mathrm{M}_{4} . \mathrm{M}_{4} 1.6 \times$ longer than stem of $\mathrm{M}_{3+4}$. Crossvein $m$-cu in line with base of $\mathrm{M}_{3+4}$ fork. CuP and $\mathrm{A}$ veins not observed. Tibial spurs absent, legs with short setae. Oviscape as long as tergite 10, sclerotized, tarered at apex; cerci and valves not apparent.

MATERIAL: Holotype VMNH 732, sex unknown; paratype VMNH 3671, + .

EтYMOLOGY: The specific epithet is a patronym honoring Drs. Wiesław Krzemiński and Ewa Krzemińska, for their significant contributions to the study of early Diptera.

\section{Metarchilimonia solita}

Blagoderov and Grimaldi, new species figures $4 a, 8 b$

Diagnosis: Differs from M. krzeminskor$u m$ by being nearly half the size, and by various venation features: stem of $\mathrm{M}_{1+2}$ longer than the fork of $\mathrm{M}_{1+2}$ (vs. longer fork); apical $\mathrm{Sc}_{2}$; discal cell longer.

DESCRIPTION: Measurements: body length 2.3-2.5 mm (holotype, 2.5), wing length 2$2.2 \mathrm{~mm}$ (holotype, 2.2). Head round, rostrum not observed. Antenna moniliform, 14-segmented, flagellomeres very slightly tapered toward apex, each with single apical seta. Only basal 8 flagellomeres well preserved. Legs densely setose, without tibial spurs. Sc short, $0.46 \times$ the wing length. $\mathrm{Sc}_{2}$ apical, its length about equal to short, distal segment of $\mathrm{Sc}_{1}$. Base of $\mathrm{R}_{5}$ oblique. Anterior margin of discal cell $1.2 \times$ longer than stem of $\mathrm{M}_{1+2}$ fork and $1.2 \times$ longer than $\mathrm{M}_{1}$. Posterior margin of discal cell $1.2 \times$ longer than $\mathrm{M}_{4}$.

Material: Holotype VMNH 3013.

ETYMology: The specific epithet is for the Solite Corporation, which has quarried the locality.

\section{INFRAORDER PSYCHODOMORPHA}

This infraorder includes the living families Tanyderidae and Psychodidae, and sometimes Ptychopteridae, the Blephariceromorpha, and Scatopsoidea. The first two families are known from the Early Jurassic (Ansorge, 1994). Psychodidae are widely distributed and their larvae breed in wet to foul substrates. Phlebotominae feed on vertebrate blood and insect hemolymph. In the widest sense this infraorder may include the following extinct taxa: Hennigmatidae, Tillyardipteridae, Rhaetaniidae, and Eoptychopteridae.

\section{FAMILY PSYCHODIDAE NEWMAN, 1834, OR NEAR}

\section{Triassopsychoda Blagoderov and Grimaldi, new genus}

Diagnosis: Wing drop-shaped, with highly reduced anal lobe; veins with long setae. Vein Sc meets $C$, ends slightly distad of basalmost fork of $\mathrm{R}$. Vein $\mathrm{R}$ with four branches, $\mathrm{M}$ with three branches, $m-m$ absent; bases of $\mathrm{R}_{4+5}, \mathrm{R}_{5}, r-m$ in apical half of wing; base of $\mathrm{M}$ faint.

Type SPECIEs: Triassopsychoda olseni n.sp.

ETYMology: The genus name is from the Triassic; the name is feminine. 

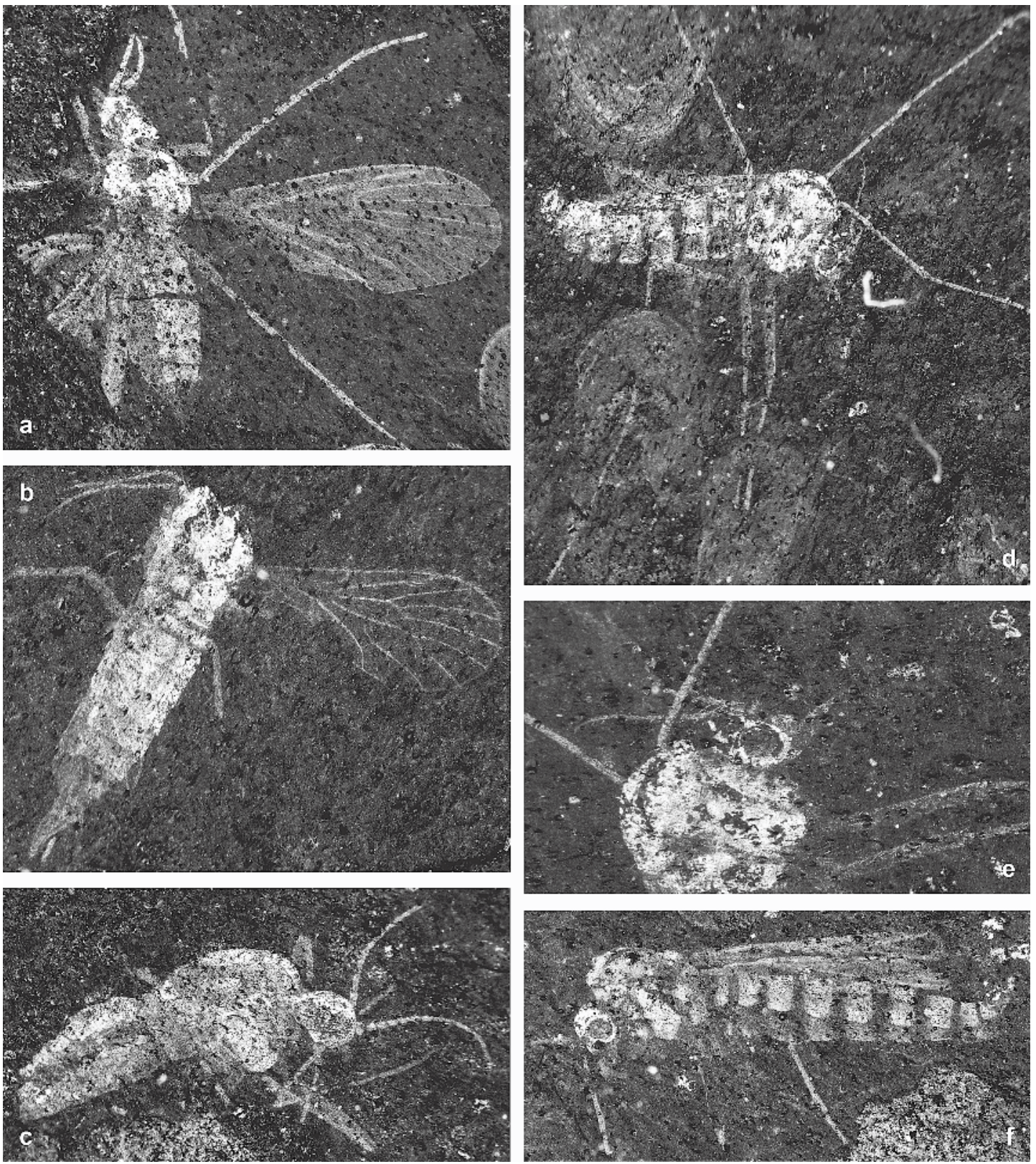

Fig. 4. Photomicrographs of tipulomorphan (a), psychodomorphan (b), and culicomorphan (c-f) Diptera from the Cow Branch Formation. a. Metarchilimonia solita Blagoderov and Grimaldi, holotype VMNH 3013. b. Triassopsychoda olseni Blagoderov and Grimaldi, holotype VMNH 733. c. Culicomorpha indet., VMNH 808. d. Culicomorpha indet., VMNH 951. e. Culicomorpha indet., VMNH 951, detail of head, showing proboscis. f. Culicomorpha indet., VMNH 932. For size scales see fig. 9. 


\section{Triassopsychoda olseni \\ Blagoderov and Grimaldi, new species}

figures $4 \mathrm{~b}, 9 \mathrm{a}$

\section{Diagnosis: As for genus.}

DESCRIPTION: Female. Measurements: body length $=2.1 \mathrm{~mm}$, wing length $=$ $1.4 \mathrm{~mm}$. Head round, eyes reniform, with large facets. Length of mouthparts, including palps, approximately $1 / 4$ height of head. Antennae with 14 flagellomeres, each with whorl of long setae; length of each flagellomere approximately $2 \times$ its width. Apex of wing broadly rounded, anal lobe absent, wing base petiolate. Wing veins with long setae including C. Costal cell very wide; Sc meets C, its length approximately $0.4 \times$ the wing length. Base of RS stem at $0.35 \times$ wing length, base of $\mathrm{R}_{3+4+5}$ fork at $0.53 \times$ the wing length, so radial-medial cell is long and wide. $R_{2}$ lost, base of $R_{4+5}$ fork distal to base of $R_{3}$. Lengths of stem of $\mathrm{R}_{4+5}$ fork, basal section of $\mathrm{R}_{5}, r-m$, and stem of $\mathrm{M}_{1+2}$ fork are subequal. Base of $\mathrm{M}_{3+4}$ is at $0.47 \times$ the wing length. Veins $\mathrm{M}_{3}$ and $i m$ absent; discal cell open and very wide. Nine segments of abdomen apparent, subequal in length. Cerci/oviscapt long, narrow, triangular, length equal that of segments 8 and 9 combined.

\section{Material: Holotype VMNH 733.}

ETyMology: The species epithet is in honour of Dr. Paul Olsen of LamontDoherty Earth Observatory, who has done the original work on the Solite quarry fossils, and who has brought tremendous insight to the Mesozoic rift basins of eastern North America.

Discussion: Despite the reduced venation (absence of $\mathrm{R}_{2}, \mathrm{M}_{3}$, base of $\mathrm{M}$ ) this fly possesses some very plesiomorphic features: the distal positions of the base of RS, and radial and medial forks, and crossveins $r-m$ and $m-c u$, and a very wide discal cell. The structure of the radial veins of the new genus resembles the living genus Horaiella Tonnoir from India and especially Eatonisca Meunier from Baltic amber (both Psychodidae), but differs from those genera by the distal position of the radial and medial forks and the absence of $\mathrm{M}_{3}$. It differs from the Early Jurassic genera Tanypsycha Ansorge, Liassopsychodina Ansorge, and Libanophlebotomus Azar et al.,
1999 , by the absence of veins $R_{2}$ and $M_{3}$, from the latter genus also by having Sc merging with $\mathrm{C}$ instead of $\mathrm{R}_{1}$.

The position of Triassopsychoda is uncertain. The reniform eye shape, setal whorls on the flagellomeres, long cerci/oviscapt, broad wing with narrow stem, reduced anal lobe, and setose wing veins are, in combination, diagnostic of Psychodidae. The striking feature of Triassopsychoda, distinguishing it from other Psychodidae is a complete loss of vein $\mathrm{M}_{3}$ while preserving crossvein $t b$ (the basalmost section of $\mathrm{M}_{4}$,). Many authors, following McAlpine (1981) interpret the posterior longitudinal vein in the hind medial fork as $\mathrm{CuA}_{1}$ (Azar et al., 1999; Duckhouse, 2000). As we discuss below (see Phylogeny), CuA in Diptera is always a nonbranched convex vein. In Psychodidae, however, vein relief is unapparent, veins tend to be equally sclerotized and the membrane weakly corrugated; longitudinal veins are long and parallel; and crossveins and fork bases are shifted proximad. Triassopsychoda, conversely, has CuA long and thick, just like in other Diptera, and the base of $\mathrm{M}_{4}$ is at the middle of the wing. Another objection against including Triassopsychoda in Psychodidae is the structure of vein $C$, which is evanescent slightly apical to the apex of $\mathrm{R}_{5}$ (vs. circumambient in Psychodidae, although this state may be plesiomorphic because some Tipulomorpha share it). Thus, despite the highly reduced venation, Triassopsychoda possesses several plesiomorphies not found in living Psychodidae.

\section{INFRAORDER CULICOMORPHA}

Culicomorpha include more than 12,000 Recent species in eight families: Ceratopogonidae, Chaoboridae, Chironomidae, Corethrellidae, Culicidae, Dixidae, Simuliidae, and Thaumaleidae. The Culicidae, Corethrellidae, Simuliidae and basal Ceratopogonidae are essentially hematophagous. Larvae of almost all culicomorphs are aquatic or live in moist habitats. About 300 fossil species are described, about $60 \%$ of which are Ceratopogonidae. The earliest known fossil of the infraorder is Aenne from the uppermost Triassic of England, which has been assigned 
to the Chironomidae (Krzemiński and Jarzembowski, 1999).

\author{
Culicomorpha indet. \\ figures $4 c-f, 5 a, b, 9 b$, c
}

Several specimens from the Solite quarries have their venation obscured, so they can not be described and named formally. Some of these specimens, however, are otherwise exquisitely preserved, retaining some distinctive features that allow placing them within the infraorder Culicomorpha. Despite differences in sizes and leg lengths, specimens VMNH 808, 873, 932, 951, 2956, and 3056 possess: (1) slender moniliform antennae with long setae on each flagellomere; (2) a round antennal pedicel that is larger than the scape; (3) round (vs. reniform or emarginate) eyes with large facets; (4) a broad katepisternum that is rounded ventrally; (5) a short, arched mesonotum that nearly overhangs the pronotum; (6) small, unprotruding scutellum; (7) wide insertion of the abdomen; and (8) male genitalia curved dorsally. Features 2, 5, and 8 are particularly distinctive to Culicomorpha, but venation is needed to confirm this. Most significantly, VMNH 951 bears a long, slender proboscis that is nearly twice as long as the head height (figs. 4d, e; 9b, c).

Body and leg proportions of VMNH 951 are very similar to that of other culicomorphans (VMNH 808, 873, 932, 2956, 3056), but it is doubtful that the specimens are conspecific, since there are no known instances in any living species of Diptera where a proboscis is so dramatically dimorphic. In various Recent species of biting midges the styletlike mandibles of females are well developed and used to puncture the skin of their host in order to feed on blood; males feed on nectar and have vestigial mandibles, but the proboscis size barely differs with that of females. Since angiosperms did not appear until nearly $100 \mathrm{Ma}$ later, it is possible that the proboscis was used to probe Bennettitalean or Gnetalean reproductive structures, and bennettitaleans occurred in the Triassic of Virginia. Recent Gnetales produce pollination droplets, on which insects feed, but these are external, making a long proboscis unnecessary. VMNH 951 is the earliest fossil evidence of a structure in Diptera specialized for blood feeding, in a group in which the ground-plan adult diet is hematophagy (Grimaldi and Engel, 2005; Lukashevich and Mostovski, 2003). If this is the case, VMNH 951 is the earliest known blood-feeding insect. It is not until the Jurassic that definitive insect ectoparasites appeared, and not until the Cretaceous that definitive hematophagous insect groups appeared (Grimaldi and Engel, 2005).

\section{INFRAORDER BIBIONOMORPHA}

The composition of the infraorder is in flux, partly because it is paraphyletic with respect to the higher flies, the Brachycera. It includes diverse Mesozoic taxa, such as Eliidae and various families of sciaroids, in addition to the families discussed below. The infraorder also includes very diverse Recent families, such as Mycetophilidae and Cecidomyiidae, totaling 8,000 species in some 25 families. In contrast to the other major infraorders of nematocerous flies, larvae of Bibionomorpha and those of their stem group (the Brachycera) are almost exclusively terrestrial, being saprophagous, fungivorous, phytophagous, and sometimes predatory.

\section{FAMILY PROCRAMPTONOMYIIDAE KOVALEV, 1985}

A small family of basal bibionomorphs known from Late Triassic to Early Cretaceous of North America, Australia, Asia, and Europe. Kovalev (in Kalugina and Kovalev, 1995) referred the family to Anisopodoidea based on the presence of a discal cell. However, a more accurate placement would be at the base of all Bibionomorpha s.l. (Shcherbakov et al., 1995).

\section{Genus Yalea Krzemiński, 2004}

Yala Krzemiński, 1992: 44. Type species: Yala argentata Krzemiński, 1992, monotypic, by original designation (preoccupied by Yala Chu, 1979 [Geometridae]).

Yalea Krzemiński, 2004: 229. Replacement name.

Diagnosis: $\mathrm{R}_{4}$ base proximal to $r-m$, section of $\mathrm{M}_{2}$ proximal to $m-m$ and section of $\mathrm{M}_{3}$ proximal to $m-m$ are nearly equal, with length $0.3-0.5 \times$ that of discal cell. 

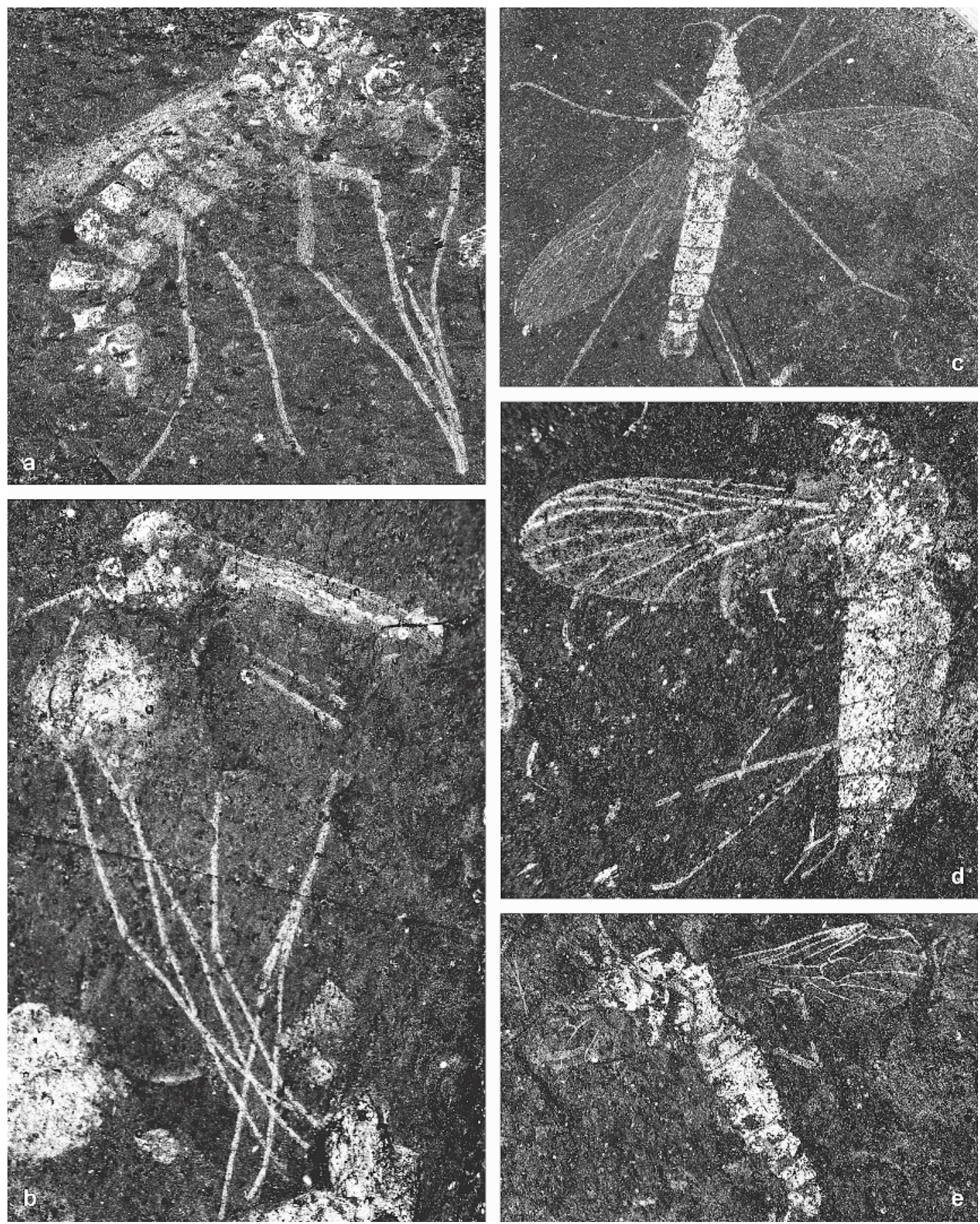

Fig. 5. Photomicrographs of culicomorphan $(\mathrm{a}, \mathrm{b})$ and bibionomorphan (c-e) Diptera from the Cow Branch Formation. a. Culicomorpha indet., VMNH 2956. b. Culicomorpha indet., VMNH 3056. c. Yalea argentata (Krzemiński). d. Yalea rectimedia Blagoderov and Grimaldi, VMNH 1041. e. Veriplecia rugosa Blagoderov and Grimaldi, YPM 35989. For size scales see fig. 10. 
InCluded Species: Yalea argentata (Krzemiński) (figs. 5c, 10b) and $Y$. rectimedia Blagoderov and Grimaldi, new species.

Yalea rectimedia Blagoderov and Grimaldi, new species

figures $5 \mathrm{~d}, 10 \mathrm{a}$

Diagnosis: Nearly $0.7 \times$ smaller than Yalea argentata. Sc shorter, ends at the level of $\mathrm{R}_{2+3}$ base (vs. slightly distad). $\mathrm{M}_{3}$ and $\mathrm{M}_{4}$ parallel (vs. slightly divergent and curved). $\mathrm{R}_{2+3} 2 \times$ the length of stem of RS (vs. $1.5 \times$ the length). Length of $\mathrm{M}_{1+2}$ stem equal to section of $\mathrm{M}_{2}$ proximal to $m-m$ (vs. $1.5 \times$ the length).

DESCRIPTION: Female. Measurements: body $=3.8 \mathrm{~mm}$, wing $=2.2 \mathrm{~mm}$. Scape and pedicel wider than flagellum, hemispheric; flagellomeres cylindrical, with lengths about equal to widths. Sc ends at $\mathrm{C}$ at level of base of $\mathrm{R}_{2+3}$. $\mathrm{R}_{1}$ almost straight, $\mathrm{R}_{2+3}$ sigmoid, curved anteriorly at apex. $\mathrm{R}_{4}$ and $\mathrm{R}_{5}$ curved posteriorly. $R_{2+3} 2 \times$ the length of the basal section of RS. Length of basal section of RS $2.5 \times$ that of section of RS between bases of $\mathrm{R}_{2+3}$ and $r$ $m$. $\mathrm{M}$ stem weak. Section of $\mathbf{M}_{1+2}$ stem proximal to $r-m 2.3 \times$ the length of stem section distal to $r-m$; length of $\mathbf{M}_{1}$ and $\mathbf{M}_{2}$ fork $3.5 \times$ that of $\mathrm{M}_{1+2}$ stem. Apex of $\mathrm{CuA}$ distal to level of $r-m$ crossvein. Cerci apparently onesegmented.

Material: Holotype VMNH 1041.

ETYMology: The species epithet is from the Latin rectus, meaning "straight", in reference to details of wing venation.

\section{Genus Alinka Krzemiński, 1992}

Alinka Krzemiński, 1992: 46. Type species: Alinka cara Krzemiński, 1992, monotypic, by original designation.

Krzemiński (1992: fig. 16) described Alinka cara as the earliest representative of Brachycera known at the time. This opinion was later critiqued by Shcherbakov et al. (1995), Grimaldi and Cumming (1999), and others. Our re-examination of the holotype (YPM 16826 [not 100000 as originally cited]) supports the placement of Alinka in the family Procramptonomyiidae. Eleven flagellomeres are preserved in the antenna, although the actual number could be greater because the apical flagellomere is incomplete and without the apical tuft of setulae originally reported (Krzemiński, 1992: fig. 6a). The only synapomorphy of Alinka with Brachycera was a short $\mathrm{R}_{4}$, but this character state appears several times in Diptera, such as in Paraxymyiidae, Eoditomyiidae, and Protorhyphidae (see below). The paratype of $A$. cara is too poorly preserved to be identified as a conspecific with certainty.

SUPERFAMILY SCIAROIDEA BILLBERG, 1820 FAMILY PARAXYMYIIDAE ROHDENDORF, 1946

This family includes basal sciaroids ("fungus gnats") with three branches of RS and a distinct, though sometimes faint base of $\mathrm{M}$. We are including in this family the Eomycetophilidae Ansorge, 1996, which is apomorphic in having $\mathrm{R}_{4}$ very short, apical, and transverse. We consider this family to be a subfamily of Paraxymyiidae. Four genera of Paraxymyiidae are known from the Late Triassic to the Early Cretaceous: Paraxymyia Rohdendorf, 1946; Veriplecia Blagoderov, 1999; Eomycetophila Kovalev, 1990; and Complecia Blagoderov, 1999.

\section{Genus Veriplecia Blagoderov, 1999}

Veriplecia Blagoderov, 1999: 12. Type species: V. clara Blagoderov, 1999, monotypic.

\section{Veriplecia rugosa Blagoderov and Grimaldi, new species \\ figures $5 \mathrm{e}, 10 \mathrm{~d}$}

Diagnosis: Differs from Veriplecia clara from the Late Triassic of Australia by the more basal position of the base of $\mathrm{R}_{2+3}$, which is slightly basal to the level of crossvein $t b$ (basal section of $\mathrm{M}_{3+4}$ stem proximal to crossvein $m-c u$ ).

DesCRIPTION: Male. Measurements: body $=3.1 \mathrm{~mm}$, wing $=2.2 \mathrm{~mm}$. Head round, eyes large, genae setulose. Antennae moniliform, with scape slightly larger than individual flagellomeres. Scutum with fine setulae; no large, bristlelike setae. Costa setulose. Sc short, $0.41 \times$ the length of wing, ends at $\mathrm{C}$ slightly proximal to level of base of $\mathrm{R}_{2+3}$. $\mathrm{Sc}_{2}$ not apparent or absent. Ratios of length of stem of $\mathrm{RS}$ : stem of $\mathrm{R}_{4+5}: \mathrm{R}_{5}$ are $1: 1: 3$. 
Crossvein $r-m$ located between bases of $\mathrm{R}_{2+3}$ and $\mathrm{R}_{4}$; length of section of RS between $r-m$ and base of $R_{4}$ is $0.5 \times$ the length of section between bases of $\mathrm{R}_{2+3}$ and $r-m$. Distinct pterostigma at apex of $\mathrm{R}_{1}$. Ratios of lengths of $\mathrm{M}$ stem, and sections of $\mathrm{M}_{1+2}$ proximal and distal of $r-m$ when straightened out are $5: 1: 1$. Basal stem of $\mathrm{M}$ evanescent toward wing base. Length of $M_{1}$ and $M_{2}$ fork $5.7 \times$ the length of stem of $\mathrm{M}_{1+2}$ distal to $r-m$. Length of $\mathrm{M}_{1+2}$ stem proximal to $r-m$ is $2.6 \times$ the $t b$ length. Crossvein $m-c u$ is $1.7 \times$ the length of $t b . \mathrm{CuA}$ very slightly curved back. 10 visible segments of abdomen; segment 3 largest, 8 smallest, 10 apparently large, covering ventrally situated genitalia. Abdomen and genitalia setose. Pair of short, protruding appendages present (probably gonostyli).

MATERIAL: Holotype YPM 35989.

ETYMOLOGY: The specific epithet is from the Latin rugosus, meaning "wrinkled", in reference to the deformed wing of the unique specimen.

\section{Virginiptera Blagoderov and Grimaldi, new genus}

Diagnosis: Costa ends slightly beyond tip of $R_{5}$. Sc ends at $C$ distal to the base of $R S$ and at the level of base of fork $\mathrm{R}_{2+3}-\mathrm{R}_{4+5}$. $\mathrm{R}$ and $\mathrm{CuA}$ considerably thicker than $\mathrm{M}$. Base of $\mathrm{R}_{2+3}$ proximal to crossvein $r-m . \mathrm{R}_{4}$ very short, $0.5 \times$ the length of RS. Stem of $M$ weak, incomplete. Crossvein $t b$ very short. CuA evenly curved. Tibial spurs (1:1:2) present, length ca. $1.3 \times$ width of tibia. Female cerci 2segmented. Male genitalia held ventrally.

The new genus is close to Complecia clara Blagoderov, 1999, from the Late Triassic of Australia, which differs from the new genus in having Sc shorter and ending free, base of $R_{2+3}$ very close to the base of $r-m$, and a more regular spacing of veins in the radial sector (ratios of the distances along $\mathrm{C}$ between tips of $\mathrm{R}_{1}, \mathrm{R}_{2+3}$, and $\mathrm{R}_{5}$ are 1.3:1.1:1.0) and in the medial sector (ratios of the distances along wing margin between apices of $\mathrm{R}_{5}, \mathrm{M}_{1}, \mathrm{M}_{2}$, $\mathrm{M}_{3+4}$, and $\mathrm{CuA}$ are 1:1.3:1.6:1.9).

TYPe SPECIES: Virginiptera certa, new species.

ETYMOLOGY: The genus name derives from Virginia, the U.S. state of origin of the fossil. The genus name is feminine.
Comments: The new genus has a venation similar to that of Paraxymyiidae (Eomycetophilinae) and Eoditomyiidae: three branches in $\mathrm{RS}$, with $\mathrm{R}_{4}$ extremely short, the base of $\mathrm{R}_{2+3}$ proximal to $r-m$, three branches of $\mathrm{M}$, and the discal cell reduced. Virginiptera differs from Eoditomyia Ansorge (Early Jurassic, Germany) by having a complete Sc, and in Eoditomyia crossveins $r-m, t b$ and $m-c u$ are nearly in line, and the base of $\mathbf{M}$ is completely reduced. It differs from Crosaphis (Anisopodoidea) by the presence of a short $\mathrm{R}_{4}$ vein.

The new genus is closely related to or within Sciaroidea based on the following features:

- Length of coxae approximately equal to thoracic height. Anisopodoidea in general have much shorter coxae (length ca. $0.3 \times$ the depth of thorax) than in Sciaroidea, the latter of which have a coxal length that may even exceed the thoracic height.

- Tibial spurs as long as the tibial diameter, and protruding at approximately $45^{\circ}$. Sciaroidea have short to extremely long tibial spurs, but the position is always protruding away from the tibia. In contrast, Anisopodoidea (including fossil Anisopodidae and Protorhyphidae) have short tibial spurs in line with the tibia.

- $\mathrm{CuA}$ is evenly curved. In most Anisopodoidea the section of $\mathrm{CuA}$ distal to $m-c u$ is apomorphically straight or sinuous.

- Abdominal tergite I lacks laterodorsal tubercles or protrusions. Sciaroidea never possess these structures.

- Anepisternum is bare. In those fossil Sciariodea for which preservation allows observation, as well as in many basal Recent sciaroids, the pleural sclerites are bare. Anisopodoidea very often have the setose pleural sclerites.

- Segment 8 is short in females. Size of the eighth segment varies in Sciaroidea and Anisopodoidea, but it is generally reduced in the former and well developed in the latter group.

- Tibiae with rows of thick dorsal setae. Anisopodoidea usually lack thick setae on the tibiae.

- MA or arculus not seen at the wing base. Anisopodoidea have a strong veinlike arculus; in Sciaroidea MA is usually 
represented only by a kink in the wing membrane at the base of $\mathrm{R}$.

Virginiptera certa Blagoderov and Grimaldi, new species

figures $6 \mathrm{~b}, 11 \mathrm{c}$

Diagnosis: $\mathrm{Sc}$ ends at $\mathrm{C}$, very slightly proximal to base of $\mathrm{R}_{2+3}$ and distal to crossvein $t b$. Crossvein $r-m$ as long as section of RS between bases of $\mathrm{R}_{2+3}$ and $r-m$. Stem of $\mathrm{M}$ slightly kinked at $r-m$ and $t b$. Length of section of $\mathrm{M}_{1+2}$ proximal to $r-m 1.6 \times$ that of $r-m$. Section of $\mathrm{M}_{1+2}$ stem distal to $r-m$ with length $1.8 \times$ that of $r-m$.

DESCRIPTION: Measurements: body length $=2.8-3.1 \mathrm{~mm}$ (holotype $3.1 \mathrm{~mm}$ ), wing length $=1.9-2 \mathrm{~mm}$ (holotype $1.9 \mathrm{~mm}$ ), antennal length $=0.6 \mathrm{~mm}$. Antennae short, approximately $0.7 \times$ thorax length; flagellum 14segmented (13-segmented in VMNH 2998); flagellomeres cylindrical, length of each ca. $0.5 \times$ the width. Scutum with short irregular setulae, no bristlelike setae, several longer setae caudally. Scutellum small, not protruding. Katepisternum wider than deep. Abdomen setulose, attachment slightly narrowed; widest at segments 3-4. Length of segment $80.5 \times$ that of segment 7 . Cerci 2 segmented. Wing: Costa ends slightly beyond tip of $\mathrm{R}_{5}, 1 / 2$ the length between tips of $\mathrm{R}_{5}$ and $\mathrm{M}_{1}$ on holotype's left wing. Sc ends at $\mathrm{C}$, slightly proximal to base of $\mathrm{R}_{2+3}$ and distal to crossvein $t b$. Sc length $0.4 \times$ the wing length. $\mathrm{R}$ and $\mathrm{CuA}$ veins distinctly thicker and more sclerotized than medial veins. $R_{1}$ length $0.67 \times$ the wing length. $\mathrm{R}_{2+3}$ nearly parallel to $\mathrm{R}_{1}$, both veins very slightly curved toward anterior margin of wing. $\mathrm{R}_{4}$ very short, straight, $0.5 \times$ the length of $R_{5}$. Ratios of distances between tips of $R_{1}, R_{2+3}$, and $R_{5}$ on $C$ are 2:2.5:1. $R_{4+5}$ stem straight basally, in apical quarter curved slightly backward, ending at wing tip. Crossvein $r-m$ as long as section of RS between bases of $\mathrm{R}_{2+3}$ and $r-m$. Stem of $\mathrm{M}$ slightly kinked at $r-m$ and $t b ; \mathbf{M}_{1+2}$ stem proximal to $r-m$ is very weak. Section of $\mathbf{M}_{1+2}$ stem distal of $r-m 1.8 \times$ that of section proximal to $r-m$. Length of section of $\mathrm{M}_{1+2}$ proximal to $r-m 1.6 \times$ that of $r-m$. Length of $\mathrm{M}_{1}-\mathrm{M}_{2}$ fork $4.2 \times$ the length of section of $\mathrm{M}_{1+2}$ distal to $r-m$. Ratios of distances at wing margin between apices of $\mathrm{R}_{5}, \mathrm{M}_{1}, \mathrm{M}_{2}, \mathrm{M}_{3+4}$, and $\mathrm{CuA}$ are $1: 1.5: 2.5: 2.5$. Crossvein $t b$ very short, but distinct. CuA evenly curved. Legs setulose, hind tibiae with distinct row of dorsal setae. Tibial spurs $1.5 \times$ the tibial diameter, protruding $45^{\circ}$ from axis of tibia.

Material: Holotype VMNH 731, $q$; paratype VMNH 2998, ô.

Etymology: The species epithet is from the Latin certus, meaning "certain".

Virginiptera similis Blagoderov and Grimaldi, new species

figures $6 \mathrm{~d}, 11 \mathrm{~b}$

Diagnosis: Size slightly less than half that of $V$. certa. $\mathrm{Sc}$ ends at $\mathrm{C}$, at the level of crossvein $t b$ and significantly proximal to level of $r-m$. Crossvein $r-m 2 \times$ longer than section of RS between bases of $\mathrm{R}_{2+3}$ and $r-m$. Length of section of $\mathrm{M}_{1+2}$ proximal to $r-m$ is $1.3 \times$ that of $r-m$. Length of section of $\mathrm{M}_{1+2}$ distal to $r-m$ is $2 \times$ that of $\mathrm{M}_{1+2}$ section proximal to $r-m$.

DESCRIPTION: Measurements: body = $1.3 \mathrm{~mm}$, wing $=1.3 \mathrm{~mm}$, antenna $=0.7 \mathrm{~mm}$. Flagellum 14-segmented, flagellomeres cylindrical. Scutum arched. Abdomen with male terminalia large and folded under apex of abdomen. Wing: Costa ends slightly beyond tip of $\mathrm{R}_{5}$. Sc ends at $\mathrm{C}$, at level of crossvein $t b$. Length of $\mathrm{Sc} 0.42 \times$ the wing length. $\mathrm{Sc}_{2}$ preserved. Length of $\mathrm{R}_{1} 0.6 \times$ the wing length. $\mathrm{R}_{2+3}$ nearly straight, curved at apex toward anterior margin of wing. Ratios of distances between tips of $R_{1}, R_{2+3}$, and $R_{5}$ on $C$ are 1.5:2.5:1. $\mathrm{R}_{5}$ short, straight; $\mathrm{R}_{4}$ slightly curved, $0.5 \times$ length of $R_{5}$. Crossvein $r-m 2 \times$ longer than section of RS between bases of $\mathrm{R}_{2+3}$ and $\mathrm{r}-\mathrm{m}$. Stem of $\mathrm{M}$ nearly straight, base evanescent. Length of $\mathrm{M}_{1+2}$ section proximal to $r-m 1.3 \times$ that of $r-m$. Length of section of $\mathrm{M}_{1+2}$ distal to $r-m$ is $2 \times$ that of section of $\mathbf{M}_{1+2}$ proximal to $r-m$. Length of $\mathbf{M}_{1}$ and $\mathbf{M}_{2}$ fork is $4 \times$ the length of $\mathrm{M}_{1+2}$ section distal to $r-m$. Crossvein $t b$ very short, but distinct. Ratios of distances between apices of $\mathrm{R}_{5}, \mathrm{M}_{1}$, $\mathrm{M}_{2}, \mathrm{M}_{3+4}$, and $\mathrm{CuA}$ at wing margin are 1:1.5:2:2. CuA evenly curved.

Material: Holotype VMNH 825, $\hat{\delta}$; paratype VMNH 1042, ô.

ETYMOLOGY: The species epithet is from Latin similis, meaning "similar to" or "resembling". 

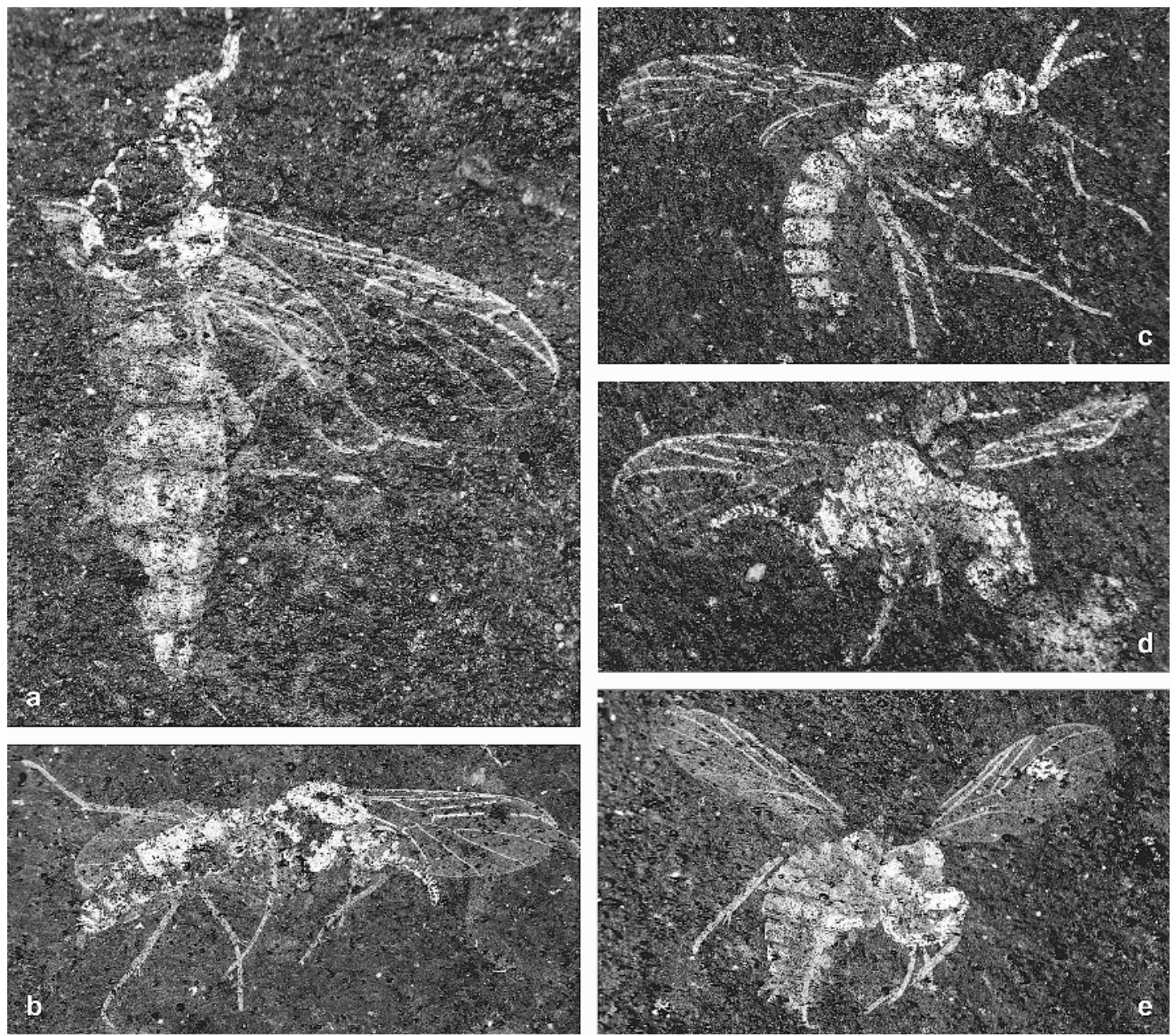

Fig. 6. Photomicrographs of bibionomorphan Diptera from the Cow Branch Formation. a. Alinka cara Krzemiński, YPM. b. Virginiptera certa Blagoderov and Grimaldi, holotype VMNH 731. c. Virginiptera certa Blagoderov and Grimaldi, paratype VMNH 2998. d. Virginiptera similis Blagoderov and Grimaldi, VMNH 825. e. Virginiptera lativentra Blagoderov and Grimaldi, holotype VMNH 2923. For size scales see fig. 11.

\section{Virginiptera lativentra}

Blagoderov and Grimaldi, new species figures $6 \mathrm{e} ; 11 \mathrm{~d}$

Diagnosis: Sc very short, ends at $\mathrm{C}$ slightly proximal to base of $m-c u$. C ends well beyond tip of $R_{5}$, almost to tip of $M_{1}$. Crossvein $r-m$ as long as section of $\mathrm{RS}$ between bases of $\mathrm{R}_{2+3}$ and $r-m$. Length of section of $\mathrm{M}_{1+2}$ proximal to $r-m 1.4 \times$ that of $r$ $m$. Length of section of $\mathrm{M}_{1+2}$ distal to $r-m$
$1.8 \times$ the length of section proximal to $r-m$; $\mathrm{M}_{3+4}$ connects directly to stem of $\mathrm{M}$.

DESCRIPTION: Measurements: body = $2.2 \mathrm{~mm}$, wing $=1.6 \mathrm{~mm}$, antennae $=$ $0.8 \mathrm{~mm}$. Palpi 5-segmented, long, length nearly equal to length of head. Flagellum 14segmented, flagellomeres cylindrical. Tibial spurs $1.5 \times$ the tibial diameter, hind tibia with a row of dorsal bristles, fore tibia with one apical spur, hind tibia with two, midtibial spurs obscured. Abdominal tergite 4 longest 
and widest. Seventh segment short, $0.5 \times$ the sixth; eighth segment very short, retracted. Ninth tergite with two triangular dorsal processes. Wing: Costa ends beyond tip of $\mathrm{R}_{5}$ at $2 /$ 3 the length between tips of $R_{5}$ and $M_{1}$. Length of Sc $0.31 \times$ the wing length. Sc ends at $\mathrm{C}$ proximal to $m-c u$. $\mathrm{R}_{1} 0.54 \times$ the wing length. $\mathrm{R}_{1}$ and $\mathrm{R}_{2+3}$ nearly parallel, straight. Ratios of distances between tips of $R_{1}, R_{2+3}$, and $R_{5}$ along $\mathrm{C}$ are 1.2:1.6:1. $\mathrm{R}_{4+5}$ stem and $\mathrm{R}_{2+3}$ divergent for entire length. $\mathrm{R}_{4}$ short, straight, $0.5 \times$ length of $\mathrm{R}_{5}$. Crossvein $r-m$ as long as section of RS between bases of $\mathrm{R}_{2+3}$ and $r-m$. Stem of $M$ weak, but can be traced nearly to base of wing. Length of section of $\mathrm{M}_{1+2}$ stem proximal to $r-m 1.4 \times$ that of $r-m$; section distal to $r-m 3.4 \times$ that of $r-m$. Fork of $\mathrm{M}_{1}$ and $\mathrm{M}_{2} 3.7 \times$ longer than its stem. Crossvein $t b$ absent, $m$-cu touches $\mathrm{M}$ stem. Ratios of distances between apices of $\mathrm{R}_{5}, \mathrm{M}_{1}, \mathrm{M}_{2}$, $\mathrm{M}_{3+4}$, and $\mathrm{CuA}$ at wing margin are 1:1.3:1.4:2.5. CuA evenly curved.

Material: Holotype VMNH 2923, VMNH 914, of (part and counterpart).

ETYMology: The species epithet is from Latin latus, meaning "wide". and venter, meaning "abdomen".

\section{SUPERFAMILY ANISOPODOIDEA KNAB, 1912}

The superfamily includes about 200 species in three small families: Mesozoic Protorhyphidae, Jurassic-Recent Anisopodidae sensu lato, and Triassic Crosaphididae. It is often believed to be the living sister group to the Brachycera (Woodley, 1989; Oosterbroek and Courtney, 1996).

\section{FAMILY PROTORHYPHIDAE HANDLIRSCH, 1906}

\section{Brachyrhyphus Blagoderov and Grimaldi, new genus}

Diagnosis: Sc $0.45 \times$ the wing length, ends at $\mathrm{C}$ slightly beyond the level of the basal fork of $\mathrm{M}$, level with base of $\mathrm{R}_{2+3}$. $\mathrm{R}_{2+3}$ slightly converging with $\mathrm{R}_{1} ; \mathrm{R}_{4} 0.25 \times$ the length of stem of $\mathrm{R}_{4+5}, 0.28 \times$ length of $\mathrm{R}_{5}$, almost straight. $\mathrm{M}$ stem faint, crossvein $m-m$ connects $\mathrm{M}_{2}$ and $\mathrm{M}_{3}$. CuA evenly curved posteriad. The new genus differs from all known Protorhyphidae by the very short vein $R_{4}$.

\section{Type Species: Brachyrhyphus distortus} n.sp.

ETymology: The genus name is from the Greek $\beta \rho \alpha \chi s$, meaning "short", and Rhyphus (a generic name in the family), in reference to the short $R_{4}$. The name is masculine.

Comments: Five genera and 10 species of Protorhyphidae are known from the Triassic to Late Jurassic-Early Cretaceous deposits of Eurasia. Vymrhyphus blagoderovi Krzemiński and Krzemińska, 2003, from the mid-Triassic of France differs from the other two species of the genus by $R_{2+3}$ converging with $R_{1}$ and diverging with $\mathbf{R}_{4}, r-m$ situated distal to $\mathbf{R}_{4}$ base, and by the very distal position of the discal cell. Thus, it could be considered as a separate genus.

\section{Brachyrhyphus distortus}

Blagoderov and Grimaldi, new species figures $7 \mathrm{a}, 11 \mathrm{e}$

\section{Diagnosis: As for genus.}

DESCRIPTION: Measurements: body length (partial) $=3.1 \mathrm{~mm}$, wing length $=1.7 \mathrm{~mm}$. Wing: $R_{1}$ straight, $R_{2+3}$ slightly sigmoid, converging but not fusing with $\mathrm{R}_{1}$. $\mathrm{R}_{4}$ almost straight, very short; length of $R_{5} 3.5 \times$ that of $\mathrm{R}_{4}$. Section of RS between $\mathbf{R}_{2+3}$ and $r-m$ about equal to length of $r-m$. Costa continues beyond apex of $R_{5}$ at least $1 / 2$ distance between the apices of $R_{5}$ and $M_{1}$ (this portion of both wings not completely preserved). Crossveins $r$ $m$ and $t b$ near the middle of the discal cell. Crossvein $m-m$ connects $\mathbf{M}_{2}$ and $\mathbf{M}_{3}$. M stem short, evanescent. Apices of $\mathrm{M}_{1}, \mathrm{M}_{2}, \mathrm{M}_{3}$, and $\mathrm{M}_{4}$ almost evenly spaced at wing margin. Distance at wing margin between apices of $\mathrm{M}_{4}$ and $\mathrm{CuA} 2 \times$ the distance between apices of $\mathrm{CuA}$ and $\mathrm{CuP}$.

Material: Holotype VMNH 2927, ㅇ.

ETYMology: The species epithet is from the Latin distortus, meaning "distorted", in reference to the distorted proportions of the specimen as a result of fossilization.

Comments: The new genus from the Virginia Triassic is unique among Protorhyphidae in its possession of a very short $R_{4}$. A distal shift and reduction of $\mathrm{R}_{4}$ is common among Bibionomorpha s.l. (Alinka, Paraxymyiidae, Eoditomyiidae) and Brachycera, and probably is a result of costalization (see below 

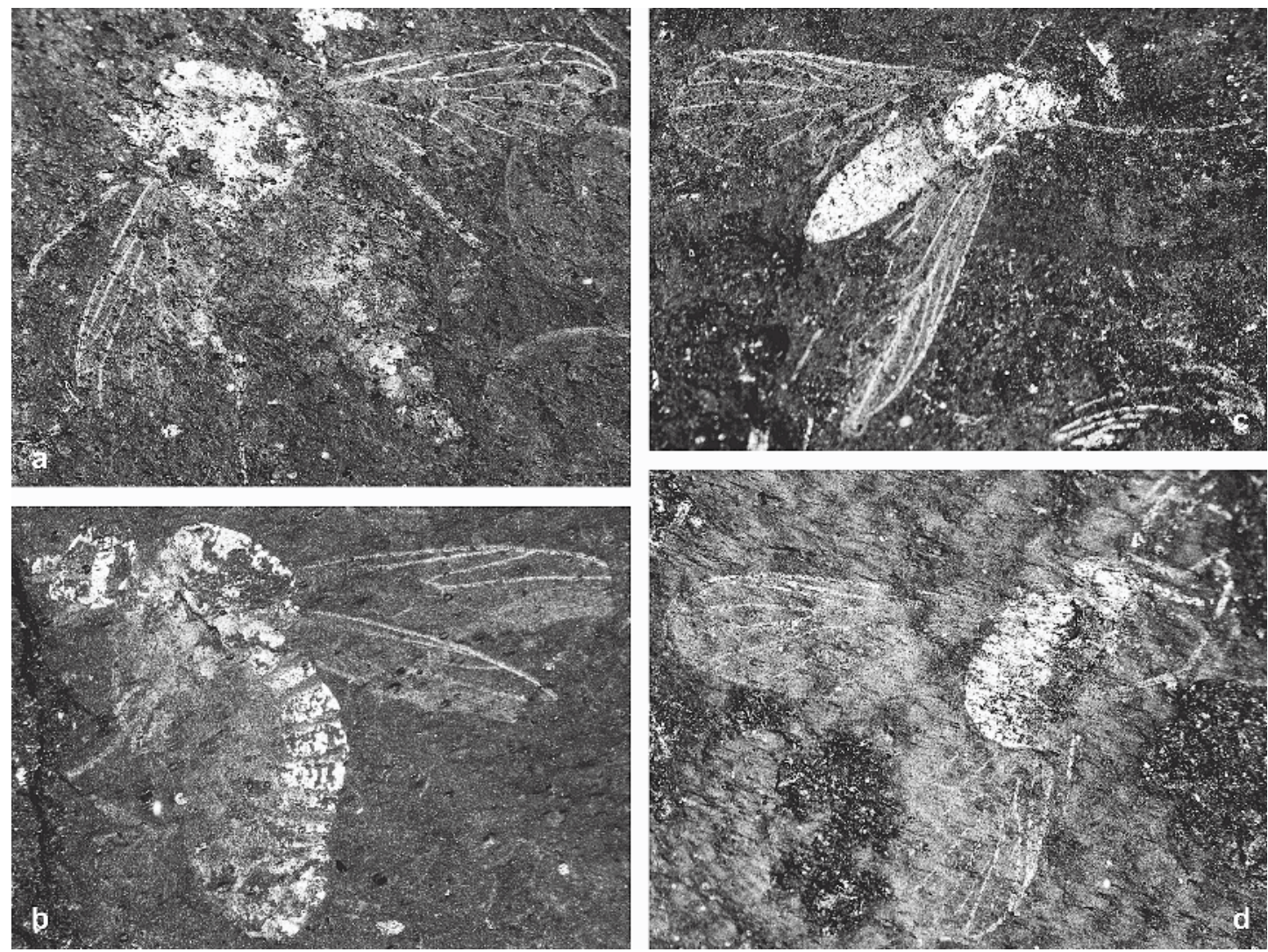

Fig. 7. Photomicrographs of bibionomorphan (a, b) and possible stem-group brachyceran (c, d) Diptera from the Cow Branch Formation. a. Brachyrhyphus distortus Blagoderov and Grimaldi, holotype VMNH 2927. b. ?Crosaphis virginiensis Blagoderov and Grimaldi, holotype VMNH 797. c. Prosechamyia trimedia Blagoderov and Grimaldi, holotype VMNH 1371. d. Prosechamyia dimedia Blagoderov and Grimaldi, VMNH 957. For size scales see fig. 12.

"Phylogeny"). Anisopodidae, which appears to be a sister group or crown-group relative of Protorhyphidae, have lost $\mathrm{R}_{4}$, thus the new genus demonstrates an intermediate condition between the two families.

\section{FAMILY CROSAPHIDIDAE KOVALEV, 1983}

\section{?Crosaphis virginiensis}

Blagoderov and Grimaldi, new species figures $7 \mathrm{~b}, 12 \mathrm{a}$

Diagnosis: Sc short, ends considerably proximal to base of RS; tip of $\mathrm{R}_{1}$ at level of base of $M_{1+2}$ fork; base of $R_{2+3}$ distal to base of $\mathrm{M}_{3+4}$.

Description: Male. Mesurements: body length $=1.78 \mathrm{~mm}$, wing $=1.36 \mathrm{~mm}$.
Antennae moniliform with 12-13 flagellomeres, flagellomere length nearly equal to the width; scape and pedicel rounded, slightly wider than flagellum. Anterodorsal tubercles may be present on first abdominal tergite. Wing: Sc short, its length $0.28 \times$ the wing length, meets $\mathrm{C}$ well before the base of RS. Sc not apparent. $\mathrm{R}_{4}$ absent. Base of $\mathrm{R}_{2+3}$ distal to the base of $\mathrm{M}_{3+4}$. Stem of $\mathrm{M}_{1+2}$ fork at least $2 \times$ the length of section of $\mathrm{M}_{1+2}$ proximal to $r$ $m$. Very slight angle in $\mathrm{CuA}$ kinked at $m-c u$, apical part of $\mathrm{CuA}$ straight. Legs either without or with very short tibial spurs. Abdomen broad and short, with hemispheric apical segment, presumably of genital capsule including gonocoxites.

Material: Holotype VMNH 797, $\hat{\jmath}$. 


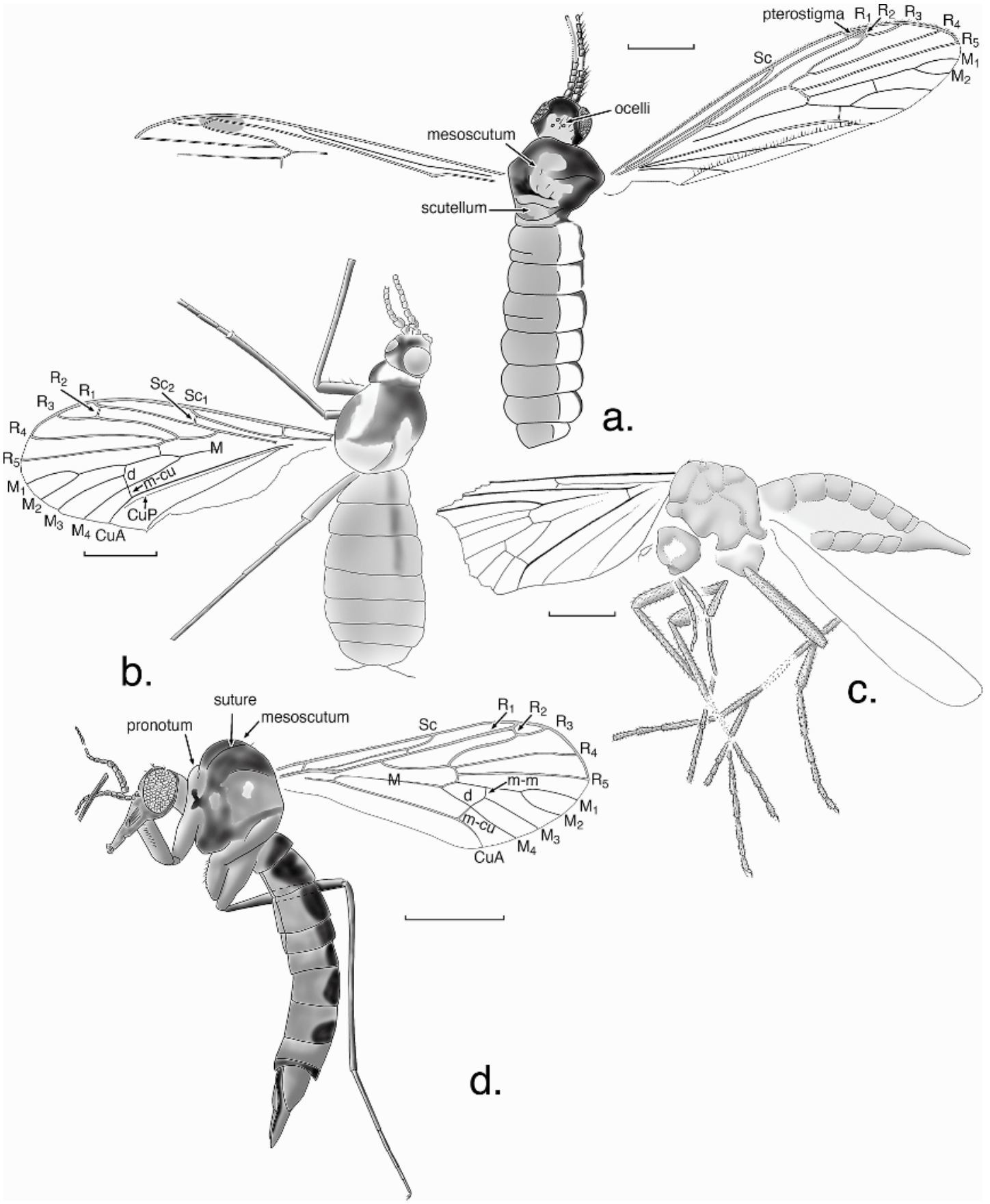

Fig. 8. Tipulomorpha from the Solite quarries. a. Architipula youngi Krzemiński YPM 35986 (Architipulinae) b. Metarchilimonia solita Blagoderov and Grimaldi, VMNH 3013. c. Metarchilimonia krzeminskorum, VMNH 3672. d. Metarchilimonia krzeminskorum Blagoderov and Grimaldi, VMNH 732. Scales $=0.5 \mathrm{~mm}$. 


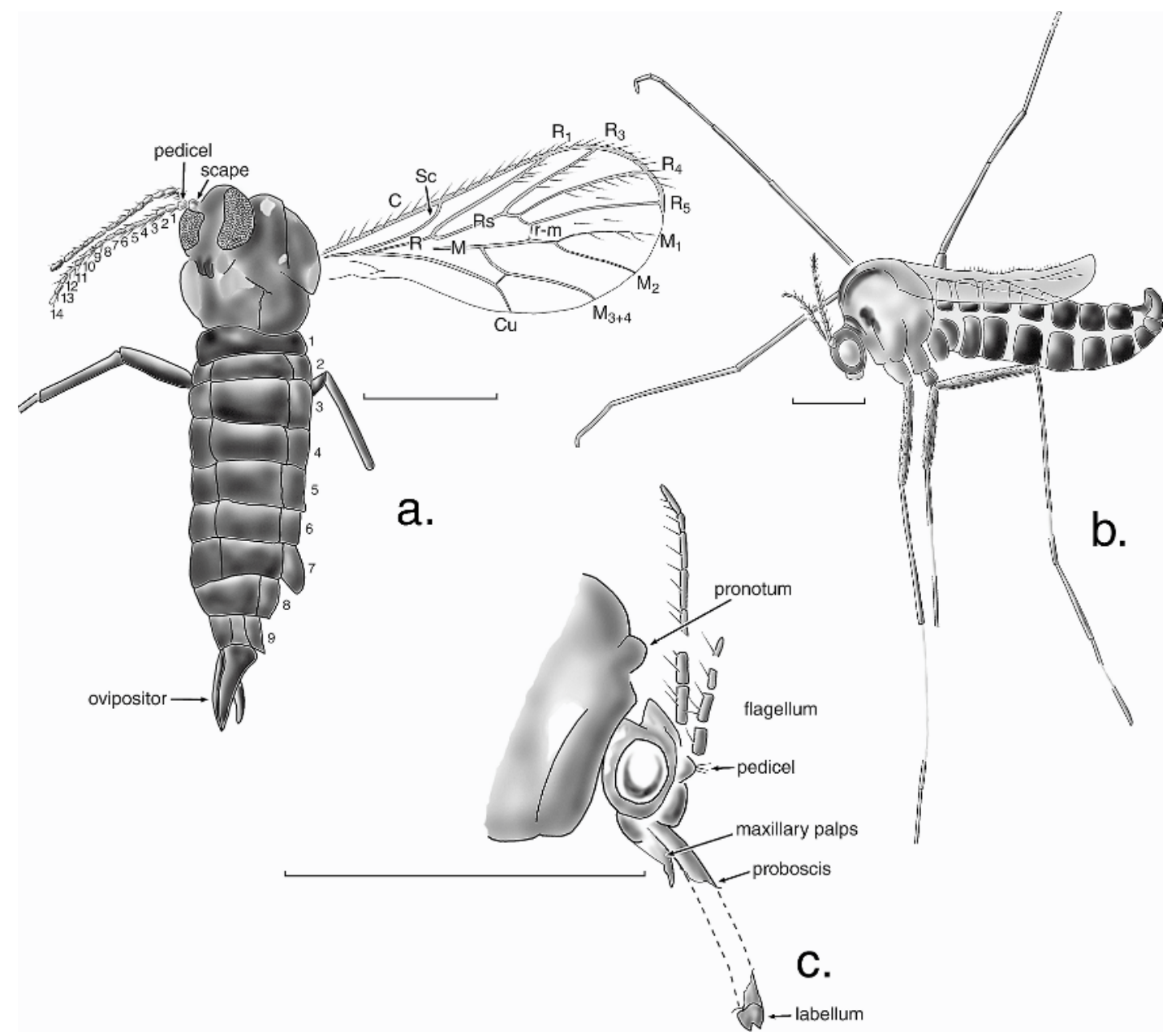

Fig. 9. Psychodomorpha and Culicomorpha from the Solite quarries. a. Triassopsychoda olseni Blagoderov and Grimaldi (?Psychodidae), VMNH 733. b. Culicomorpha (Chironomoidea?), VMNH 951. c. Detail of head of culicomorphan VMNH 951 (obverse), showing a long proboscis. Long proboscides in Culicomorpha are generally associated with blood feeding, so this may be the earliest instance of specialization for blood feeding in the fossil record. Scales $=0.5 \mathrm{~mm}$.

ETymology: From Virginia, the state of origin of the fossil.

Discussion: ?Crosaphis virginiensis is smaller than the other described Bibionomorpha from the Solite quarries. It differs from Paraxymyidae by the longer stem of $\mathrm{M}_{1+2}$, which is at least $2 \times$ longer than the section of $\mathbf{M}_{1+2}$ proximal to $r-m . \mathrm{R}_{4}$ is either absent or not apparent because the apex of the wing is not preserved. The apical part of $\mathrm{CuA}$ is almost straight. These features ally this species with Crosaphis, and the short coxae, which are smaller than in Sciaroidea, together with short or no apparent tibial spurs, suggest the species belongs in Anisopodoidea.

Incomplete preservation of the type species indicates that this species can only tentatively be assigned to the genus Crosaphis. Crosaphis anomala Evans, 1956, was described from a single wing impression from the Late Triassic of Australia. After restudying the fossil, V. Kovalev (1983) concluded that it did not belong to Hemiptera, as Evans supposed, but rather was close to mycetobiine Anisopodidae. Restudy of the holotype of Crosaphis anomala in the Queensland Museum 


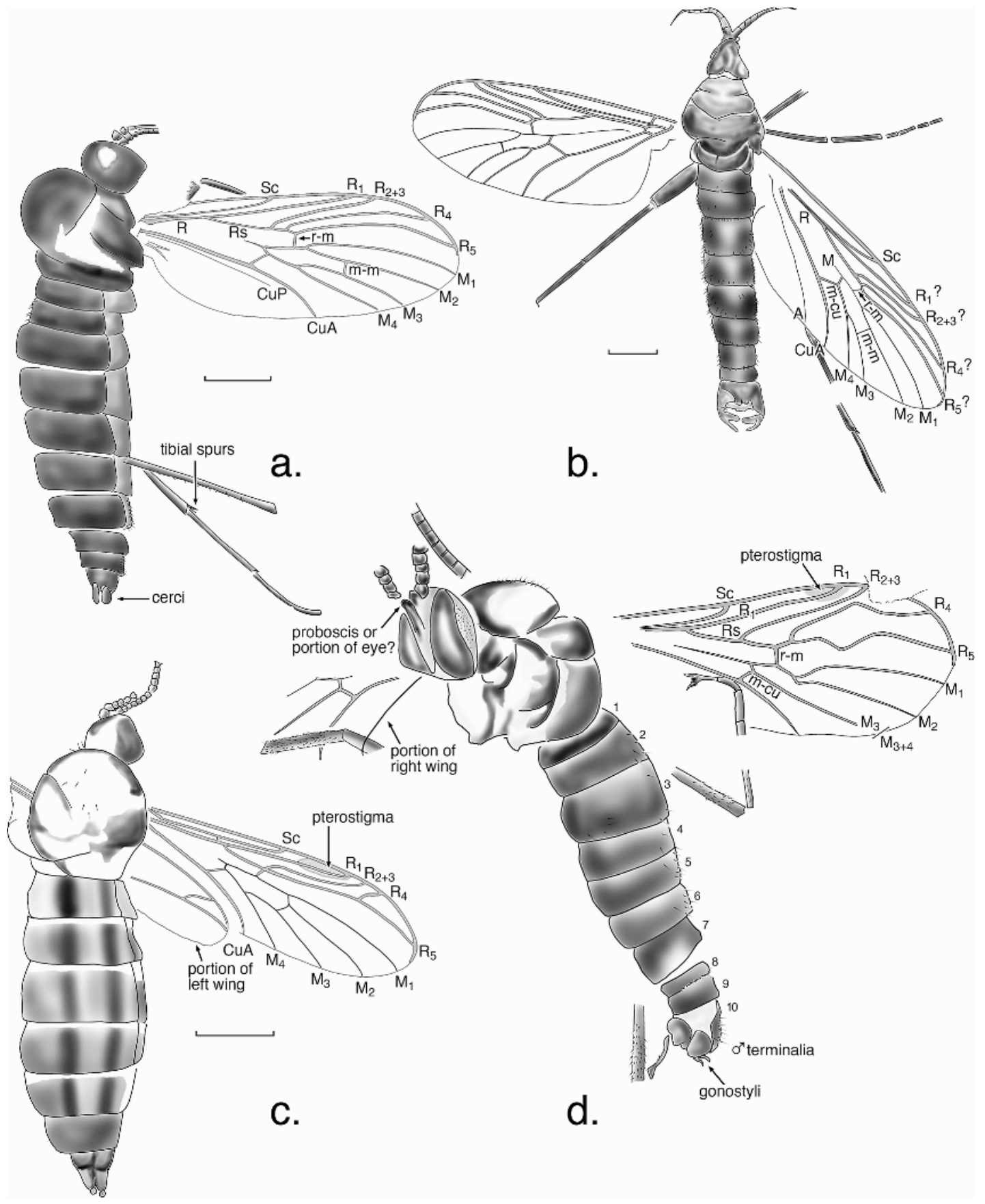

Fig. 10. Bibionomorpha from the Solite quarries. a. Yalea rectimedia Blagoderov and Grimaldi (Procramptonomyiidae), VMNH 1041. b. Yalea argentata (Krzemiński) (Procramptonomyiidae), VMNH 3673. c. Alinka cara Krzemiński (Procramptonomyiidae), YPM. d. Veriplecia rugosa Blagoderov and Grimaldi (Paraxymyiidae), VMNH 35989. 


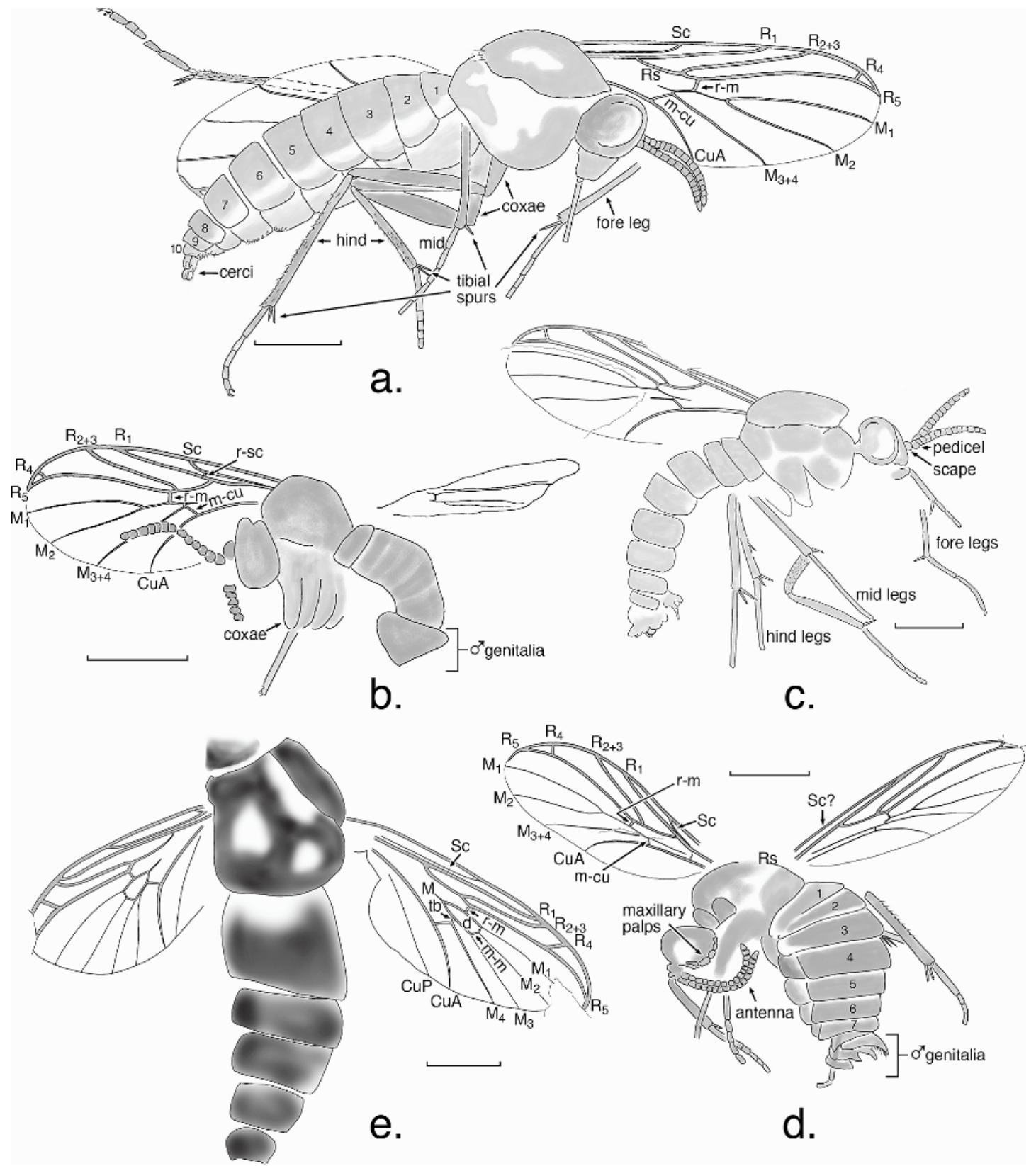

Fig. 11. Bibionomorpha from the Solite quarries. a. Virginiptera certa Blagoderov and Grimaldi, female, VMNH 731. b. Virginiptera similis Blagoderov and Grimaldi, VMNH 825. c. Virginiptera certa, male, VMNH 2998. d. Virginiptera lativentra Blagoderov and Grimaldi, holotype male, VMNH 2923. e. Brachyrhyphus distortus Blagoderov and Grimaldi (Protorhyphidae), VMNH 2927. Not to the same scale (scales $=0.5 \mathrm{~mm}$ ). 


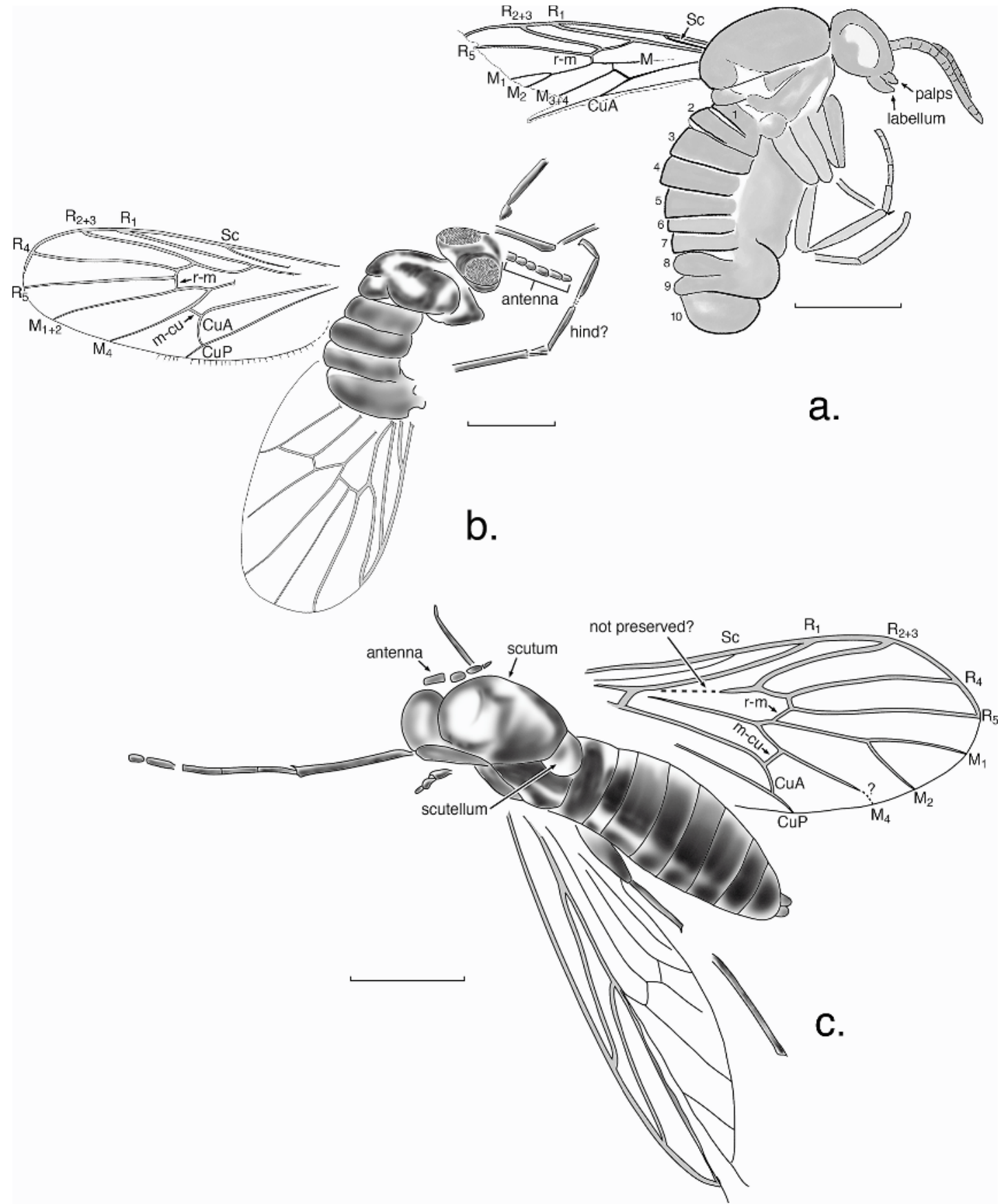

Fig. 12. Assorted Diptera from the Solite quarries. a. ?Crosaphis virginiensis Blagoderov and Grimaldi (Crosaphididae: Anisopodoidea). VMNH 797. b. Prosechamyia dimedia Blagoderov and Grimaldi (Prosechamyiidae), VMNH 957. c. Prosechamyia trimedia Blagoderov and Grimaldi, VMNH 1371. Prosechamyia appears to be an extinct stem group to the large, diverse lineage of flies, the Brachycera. Scales $=0.5 \mathrm{~mm}$. 
by one of us (DG) found it to be poorly preserved. Although the presence of parts of the venation were consistent with the venation drawn by Kovalev (1983), much venation was not observable against the rough matrix. It is possible that there may have been some deterioration since Kovalev studied it. Evenhuis (Evenhuis, 1994; Krzemiński and Evenhuis, 2000) doubted the position of Crosaphis in Anisopodoidea, on account of the venation that is supposedly similar to that of Bombyliidae mythicomiine. Not only is Late Triassic far too early for a group as recently derived (phylogenetically) as Bombyliidae, but a nearly complete crosaphidid specimen indicates it is not even a brachyceran. Amorim and Tozoni (1994) placed Crosaphis in the Mycetobiidae, a living family to which crosaphids are very closely related.

STEM-GROUP BRACHYCERA FAMILY PROSECHAMYIIDAE, NEW FAMILY

Diagnosis: $\mathrm{CuA}$ meets $\mathrm{CuP}$ well before wing margin and making a closed cell, as in most Brachycera; $\mathrm{M}_{4}$ lost, as in many Bibionomorpha and some living and extinct "Rhagionidae" s.l. (e.g., Bolbomyia, Palaeobolbomyia, Mesobolbomyia, Litoleptis), m-m crossvein absent, so there is no discal cell; $r-m$ meeting $\mathrm{R}_{5} ; \mathrm{R}_{4}$ and $\mathrm{R}_{5}$ very long and connected to basal cell; antennae plesiomorphically moniliform.

Type Genus: Prosechamyia n.gen.

\section{Prosechamyia Blagoderov and Grimaldi, new genus}

Diagnosis: Same as for family.

Type Species: Prosechamyia trimedia n.sp.

ETYMOLOGY: The genus name is a compound one from the Greek words $\pi \rho \circ \sigma \varepsilon \chi \eta \dot{~} \varsigma$, meaning "bordering" or "adjacent to", and $\mu v i \alpha$, meaning "fly". The name is feminine.

Discussion: The new genus has a unique combination of characters unknown for any Diptera, living or extinct. The petiolate anal cell is a synapomorphy of virtually all Brachycera (some species, such as Pseudoernia, some Rhagionidae and Bombyliidae have $\mathrm{CuA}$ and $\mathrm{CuP}$ converging but not meeting).
On the other hand, all earliest known Brachycera (Protobrachyceridae, Rhagionidae, Oligophryneidae, and others) have very generalized venation with a discal cell, four branches of vein $M$, and rather short $\mathrm{R}_{4}$ and $R_{5}$ veins. The new genus has no closed discal cell, no fork of $\mathrm{M}_{3+4}$, very long branches of $\mathrm{R}_{4}$ and $\mathrm{R}_{5}$, and moniliform antennae. All living Brachycera, and fossil ones with excellent preservation, have moderately to highly reduced antennae with differentiated antennal segments. Antennae of Prosechamyia trimedia are not preserved well enough to determine the number of flagellomeres with certainty, but apical segments are tapered, suggestive of basal Brachycera and resembling the condition observed in Litoleptis Chillcott, Arthroceras Williston (Rhagionidae), Xylophagidae, and Xylomyiidae. Differentiation of flagellomeres in $P$. dimedia is not preserved. Other synapomorphies of living Brachycera, like posterior elongation of the larval head into the prothorax, vertical movements of larval mandibles, or the reduced number of maxillary palpomeres (from five to two) in adults unfortunately could not be observed in the fossil material.

Prosechamyia definitely is not in Bibionomorpha s.l., some of which have a reduced discal cell and three branches of the radius (e.g., Protopleciidae, Crosaphididae). In those bibionomorphan groups $R_{2+3}$ is usually curved anteriorly and the tips of $R_{1}$ and $R_{2+3}$ are close to each other; the base of $\mathrm{M}_{3+4}$ is strongly kinked at $m$-cu, suggesting an ancestral state of discal cell structure similar to that of Procramptonomyiidae. The new genus has radial branches almost evenly spaced as in many Brachycera, and $\mathrm{M}$ forks symmetrically, similar to Protorhyphidae, Anisopodidae, and many basal Brachycera. The similarity in the wing venation of Prosechamyia to the Recent genus Litoleptis is especially striking: it differs from the latter by the longer fork of $\mathrm{R}_{4}$ and $\mathrm{R}_{5}$, crossvein $r-m$ connected directly to $\mathrm{R}_{5}$ and by the much longer basal cell. Thus, the only synapomorphy of the new genus with true Brachycera is a convergence of $\mathrm{CuA}$ and $\mathrm{CuP}$ forming a petiolate cell. It is probable that the new genus constitutes an extinct stem group to true Brachycera, having acquired only one of numerous brachyceran synapomorphies. 
Caution must be exercised when interpreting relationships - particularly one as dramatic as a sister group to all Brachycera-on the basis of one character. An interesting example of independent evolution of brachyceran characters occurs in some Archizelmiridae, a family of basal Sciaroidea from the Late Jurassic to Late Cretaceous. In one species of this family the antenna is very similar to that in Brachycera, complete with apical flagellomeres modified into a hairlike arista (Grimaldi et al., 2003). If such striking convergence can occur in a relatively complex structure, it seems at least equally probable for there to be convergence in the structure of vein $\mathrm{Cu}$ as well.

\section{Prosechamyia trimedia}

Blagoderov and Grimaldi, new species figures $7 \mathrm{c}, 12 \mathrm{c}$

Diagnosis: Three medial veins, $\mathbf{M}_{1}$ and $\mathrm{M}_{2}$ strongly divergent; base of $\mathrm{M}_{1+2}-\mathrm{M}_{3+4}$ fork at the level of $R_{2+3}$ base; $R_{4}$ and $R_{5}$ connected directly to basal cell, without a stem; length of $r-m$ nearly equal to basal section of $\mathrm{M}_{1+2}$; basal section of $\mathrm{M}_{3+4}$ twice the length of basal sections of $\mathrm{M}_{1+2}$.

DesCRIPTION: Measurements: body length $1.9 \mathrm{~mm}$, wing length $1.7 \mathrm{~mm}$. Head round, eyes large. Only four flagellomeres seen, but these are widely separated and presumably some were lost; flagellomeres tapered in width apicad, presumably apical one 1/4 size of most basal preserved one. Sc ends at $\mathrm{C}$ at level of base of $R_{2+3}$. Sc is $0.42 \times$ length of wing. $R_{1}$ short, $0.58 \times$ the wing length. Base of $\mathrm{RS}$ apparently not preserved. Crossvein $r-m$ oblique, connecting to $\mathrm{R}_{5}$ near its base. Length of $\mathrm{R}_{4+5} 2 \times$ the length of basal section of $\mathrm{R}_{5}$ and $1.5 \times$ the length of $r-m$. Base of $\mathrm{M}_{1+2^{-}}$ $\mathrm{M}_{3+4}$ fork at the level of the base of $\mathrm{R}_{2+3}$. Stem of $\mathrm{M}_{1+2} 1.2 \times$ that of $\mathrm{M}_{1}$, the section distal to $r-m$ equal in length to $\mathbf{M}_{1} \cdot \mathbf{M}_{2}$ widely divergent from $\mathrm{M}_{1}$. Basal section of $\mathrm{M}_{3+4} 2 \times$ the length of basal section of $\mathrm{M}_{1+2}$. Crossvein $m-m$ and vein $\mathrm{M}_{3}$ absent. $\mathrm{M}_{4}$ incompletely preserved in unique specimen. $\mathrm{CuA}$ forms closed anal cell with $\mathrm{CuP}$, with stem approximately equal to length of $m-c u$. Legs rather long, slender, no tibial spurs visible. Eight visible segments of abdomen, terminalia not apparent, sex unknown.

Material: Holotype VMNH 1371.

ETYMOLOGY: In reference to the number of medial veins.

\section{Prosechamyia dimedia}

Blagoderov and Grimaldi, new species figures $7 d, 12 b$

Diagnosis: Differs from $P$. trimedia by: vein $\mathbf{M}_{1+2}$ simple, not forked; $\mathrm{M}_{1+2}-\mathrm{M}_{3+4}$ stem proximal to level of $\mathrm{R}_{2+3}$ base (vs. at the same level); $r-m 0.5 \times$ the length of basal section of $\mathrm{M}_{1+2}$ (vs. nearly equal), and $r-m$ transverse (vs. oblique); basal sections of $\mathrm{M}_{1+2}$ and $\mathrm{M}_{4}$ (proximal to $r-m$ and $m-c u$ ) equal in length (vs. basal section of $\mathrm{M}_{4}$ twice the length).

DesCRIPTION: Measurements: body length $1.7 \mathrm{~mm}$, wing length $1.8 \mathrm{~mm}$. Head and eyes large. Six segments of antenna visible, only slightly tapered to most apically preserved flagellomere. Sc ends at C; its length $0.4 \times$ wing length. Length of $\mathrm{R}_{4+5} 2 \times$ that of basal section of $\mathrm{R}_{5}$ and $1.2 \times$ the length of $r-m$. Crossvein $r-m$ transverse, veins $\mathrm{M}_{1+2}$ and $\mathrm{M}_{3+4}$ simple (apparently $\mathrm{M}_{2}$ and $\mathrm{M}_{3}$ lost), $m$-cu absent. Basal sections of $\mathbf{M}_{1+2}$ and $\mathbf{M}_{3+4}$, proximal to crossveins $r-m$ and $m-c u$ respectively, are subequal. Tibia (hind) with at least one tibial spur, slightly longer than tibial diameter. End of abdomen curled ventrally; sex unknown, but probably male.

MATERIAL: Holotype VMNH 957.

ETYMOLOGY: In reference to the number of medial veins.

\section{DISCUSSION}

\section{Phylogeny}

This study is an attempt to determine the phylogenetic placement of early fossils of the order Diptera; it is not intended to be the definitive solution to the poorly understood relationships among nematocerous flies. Nematoceran phylogeny has proven problematic thus far, and there is significant disagreement among the major studies. Disagreement may be due to the fact that most of these studies have been based on certain character systems; alternatively, the major lineages may have arisen contemporaneously or nearly so 
(and so relationships would be difficult to decipher). Many studies, for example, hypothesize that Tipulomorpha is the sister group to the rest of the Diptera (Hennig, 1954, 1973; Wood and Borkent, 1989; Michelsen, 1996), but one major study hypothesizes that the Tipulidae is much more recently derived and very closely related to the Brachycera (Oosterbroek and Courtney, 1995). Several studies have been largely or wholly relegated to characters of immatures (Wood and Borkent, 1989; Sinclair, 1992); or to particular areas of the adult body, such as the cervical region (Michelsen, 1996) or venation, particularly of fossils (Krzemiński and Krzemińska, 2003; Shcherbakov et al., 1995). Phylogenetic hypotheses by Hennig (1954, 1973) and Oosterbroek and Courtney (1995) were based on immatures and adults. Oddly, there is no comprehensive study of nematoceran relationships based on DNA sequences, and the only one that has been done was based on one gene and minimal taxon sampling (Friedrich and Tautz, 1997). Other DNA studies, mentioned below, have focused on particular infraorders or families. A serious caveat of DNA studies, of course, is that they cannot incorporate fossil DNA, and so they must incorporate morphological structures of living and fossil species to understand the placement of extinct taxa. No study has incorporated many morphological characters of living and extinct Diptera.

We examined the phylogeny of living and extinct Diptera using the morphology of 75 exemplar taxa, representing 45 Mesozoic genera and 30 basal genera of living families of nematocerous Diptera, and two basal families of living Brachycera (Xylomyidae and Xylophagidae). Eighty morphological characters were studied, which represented most major body structures but also included external and internal genitalia of both sexes. Of the 80 morphological characters, $37(46 \%)$ of them were based on wing structure, shape, and venation, which is essential for interpreting Triassic fossil Diptera since most of these taxa are wholly or largely defined by venation. Of the 6,000 cells in the data matrix, 1,891 $(31 \%)$ of them were not scored or were considered ambiguous because of sexual dimorphism or incomplete preservation of fossils. Most of these unscored cells were characters 30-74 and pertain to minute structures on the body that are generally obscured in compression fossil insects. Most characters were coded for just two states $(0$, plesiomorphic; 1, apomorphic), but 11 characters with two or more apomorphic states were also scored. With the exception of character 80 , all states were nonadditive. The phylogenetic program NONA (Goloboff, 1999) was used, employing the parsimony ratchet with 200 iterations (10 trees per iteration), which generated 264 most-parsimonious trees (MPTs) of length 324, CI 30, RI 72. Figure 13 is the strict consensus of these MPTs, which is some 51 steps longer (L 375, CI 26, RI 66). As expected with a consensus tree, there is less resolution than in the MPTs, in this case primarily among the basal Bibionomorpha. Otherwise, the relationships within the other infraorders and major taxa are well resolved in the consensus tree.

Tipulomorpha in the present study is the sister group to the remaining Diptera, as is traditionally hypothesized (e.g., Hennig, 1954, 1973; Wood and Borkent, 1989), and there is a significant grade of extinct taxa in this infraorder from the Triassic to the present. The infraorder typically includes just the Tipulidae s.l. (or Tipulidae s.s, Cylindrotomidae s.s., and Limoniidae s.s.), though sometimes the winter crane flies, family Trichoceridae, are also included (e.g., Oosterbroek and Courtney, 1995). Typical breeding sites of tipulids are the sediments of shallow streams and ponds, and organically rich mud and wet soils; trichocerids breed in decayed wood. Tipulidae s.1. is the largest family of Diptera with approximately 14,000 described species.

Blephariceromorpha in this study is represented by only one Recent taxon (Edwarsina: Blephariceridae) and a primitive Jurassic genus, Ansorgius. Deuterophlebiidae is another Recent family in the group, and monophyly of the infraorder is essentially certain. The odd, neotenic family Nymphomyiidae is related either to these (Oosterbroek and Courtney, 1995; Wood and Borkent, 1989) or it belongs to the Culicomorpha (Courtney, 1994). This infraorder, which is the smallest one (approximately 100 species worldwide), is 


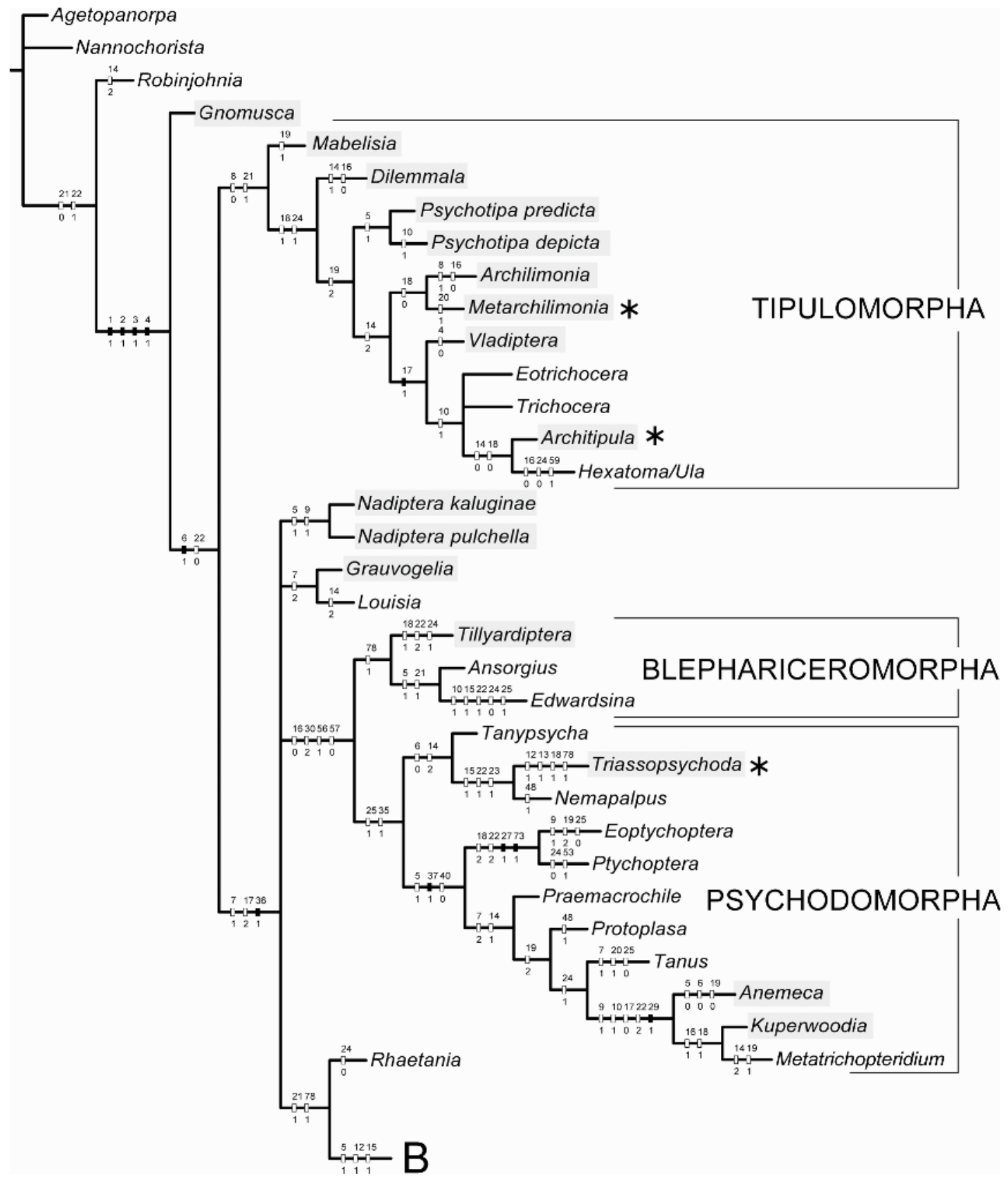

Fig. 13. Strict consensus tree (L 375, CI 26, RI 66) of 264 most-parsimonious trees, based on 80 morphological characters of 75 exemplar genera of Diptera (45 of them Mesozoic; see tables 2, 3). Shaded taxa are from the Triassic (others are later Mesozoic and Cenozoic); those with an asterisk are from the Solite quarries. Major infraorders of the Diptera appeared by the Late Triassic. 


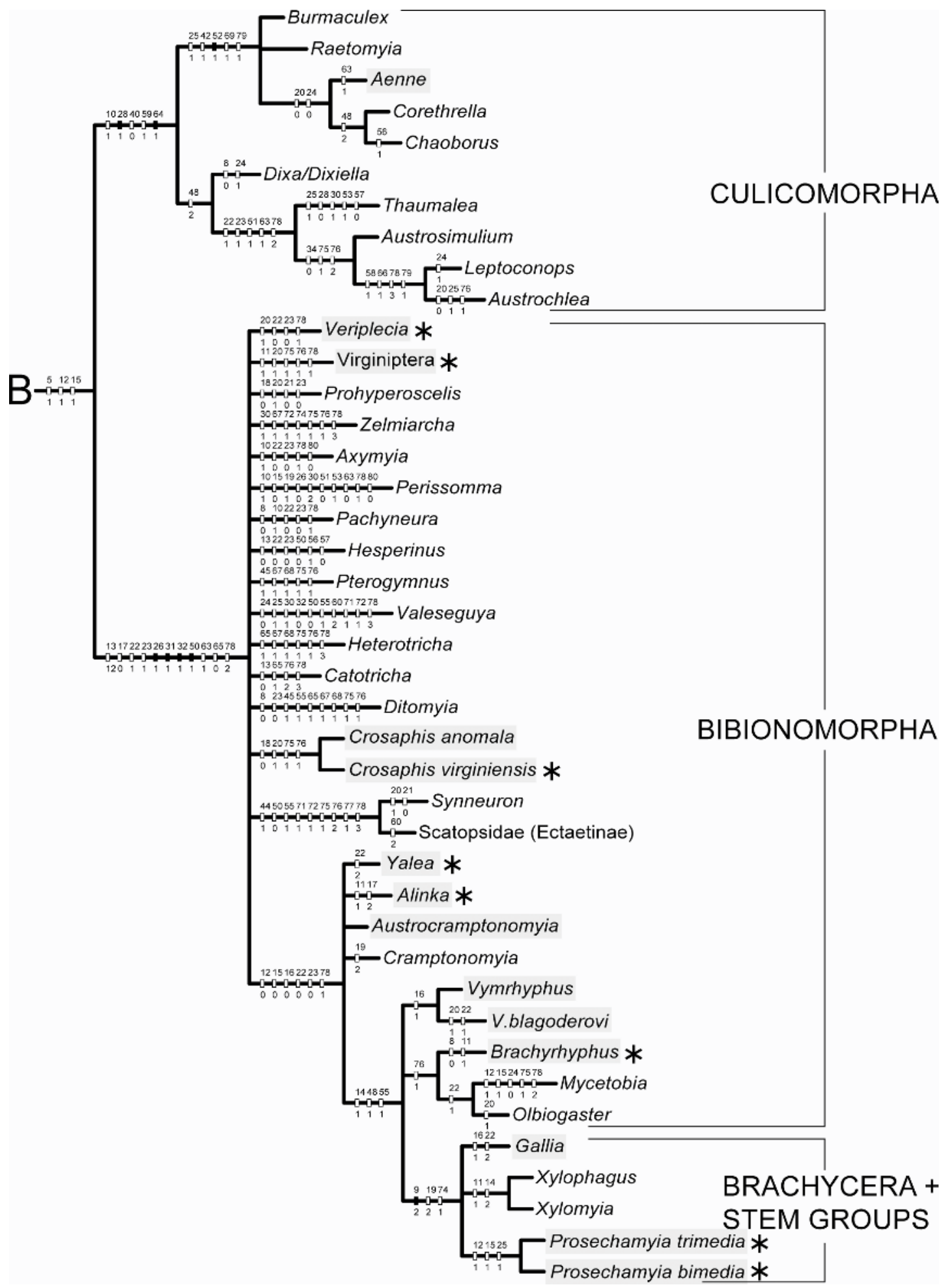

Fig. 13. Continued 


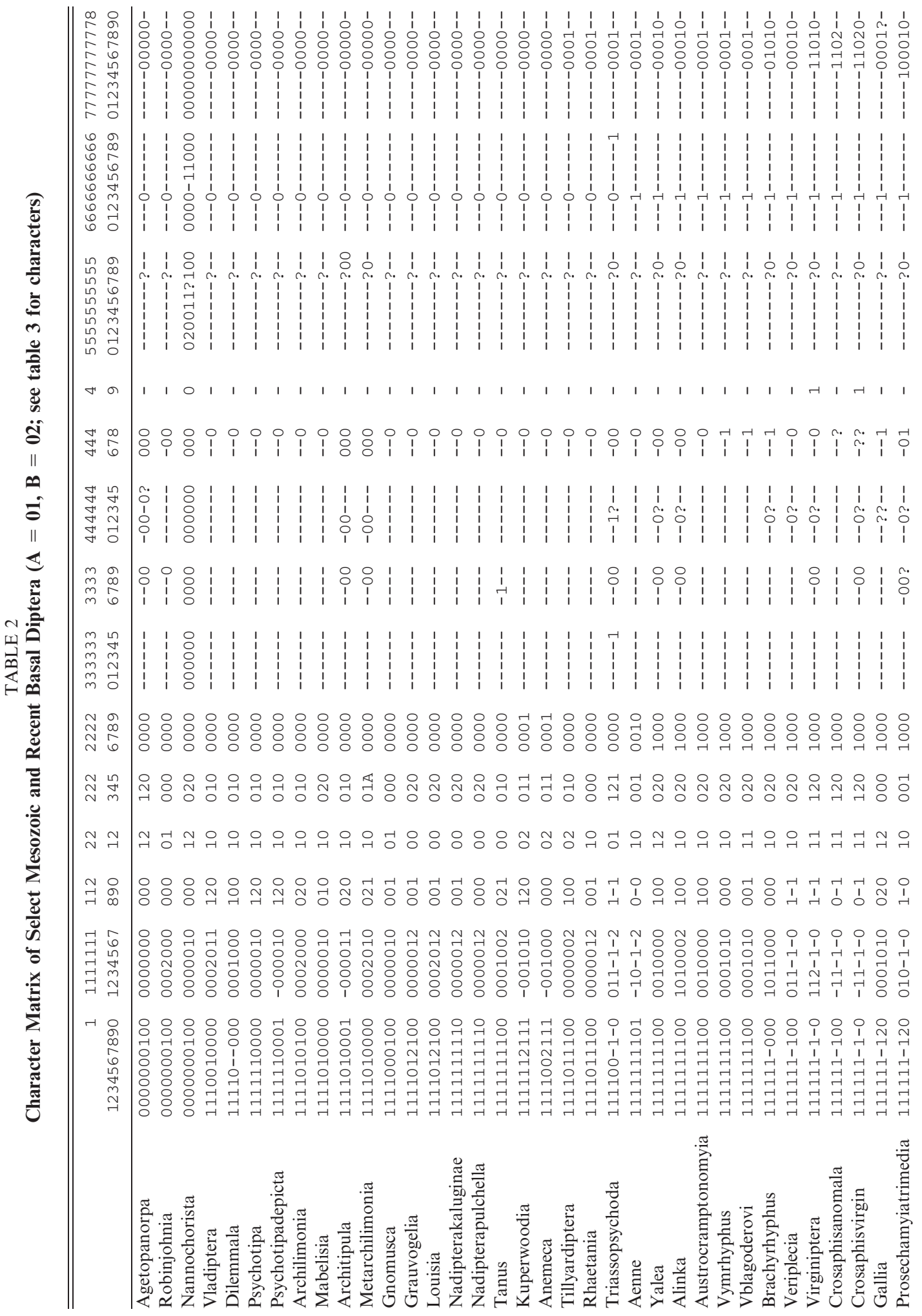




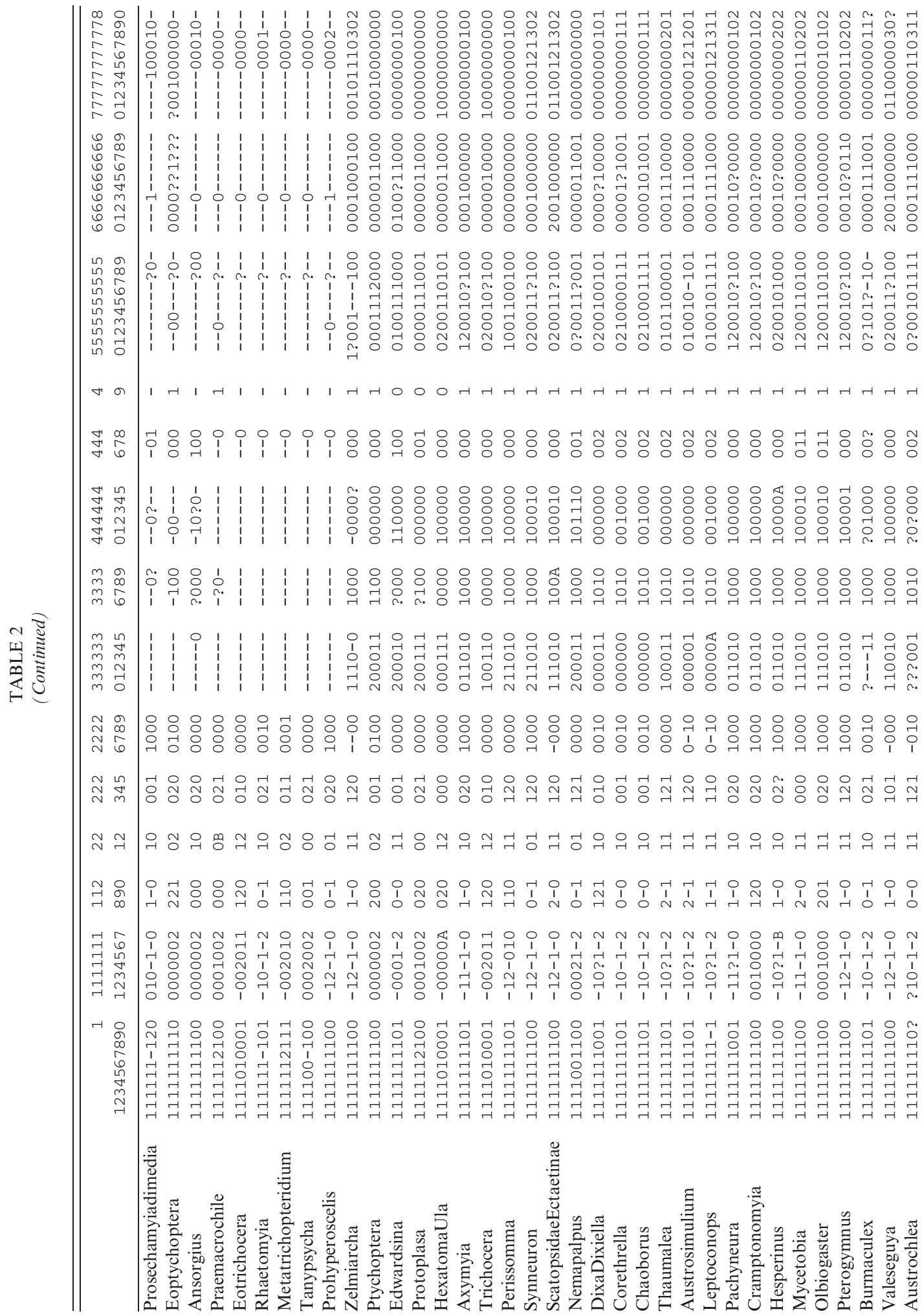




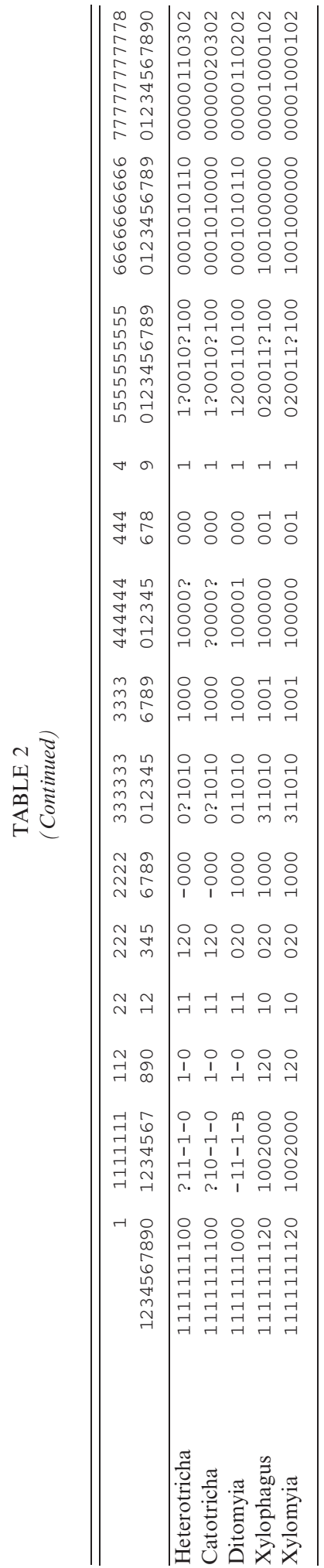

closely related to the Psychodomorpha in our analysis. Larvae live on rocks in shallow, cold, swift streams, especially near waterfalls.

The infraorder Psychodomorpha has been one of the most problematic of all major lineages in the Diptera. It typically contains the family of moth flies, Psychodidae (Michelsen, 1996; Oosterbroek and Courtney, 1995), but some authors also include in this infraorder the phantom crane flies (Ptychopteridae) and Tanyderidae (Hennig, 1973; this study), as well as the blephariceromorphs (Hennig, 1973). Wood and Borkent (1989) included in this infraorder the Psychodidae, Trichoceridae, Perissommatidae, Anisopodidae, and Scatopsoidea. Psychodidae and Scatopsoidea breed in wet, foul substrates.

Culicomorpha is the least problematic of the major infraorders, since there is good consensus on the monophyly, composition, and relationships (Hennig, 1954, 1973; Wood and Borkent, 1989; Oosterbroek and Courtney, 1995; Miller et al., 1997; Pawlowski et al., 1997). Our results likewise indicate a monophyletic Culicomorpha, but relationships differ slightly with the other major studies, perhaps because of minimal sampling in this study. Aenne, which is known from the Triassic of Britain (Krzemiński and Jarzembowski, 1999) to the Cretaceous of Lebanon (in amber), belongs to the Chironomidae, so in the cladogram in figure 13 it should be the sister group to the other chironomid, which is the very basal living genus Austrochlea. Culicomorphan larvae are essentially aquatic, and the ancestral diet of adult females is insect hemolymph and/or vertebrate blood (Grimaldi and Engel, 2005). An undetermined culicomorphan from the Solite quarries reported here has a long proboscis, which is suggestive of its use in sucking blood. As such, it would be the oldest known example among insects of a structure specialized for blood feeding.

Bibionomorpha is a large, complex infraorder whose monophyly is well supported in this study, though internal relationships are poorly resolved. Better resolution is indicated by some studies, such as the close relation of Valeseguya (Valeseguyidae) to the Scatopsoidea (Scatopsidae + Synneuridae; Amorim and Grimaldi, 2006). Relationships 
TABLE 3

\section{Characters Used in Phylogenetic Analysis of Select Mesozoic and Recent Basal Diptera ${ }^{\mathrm{a}}$}

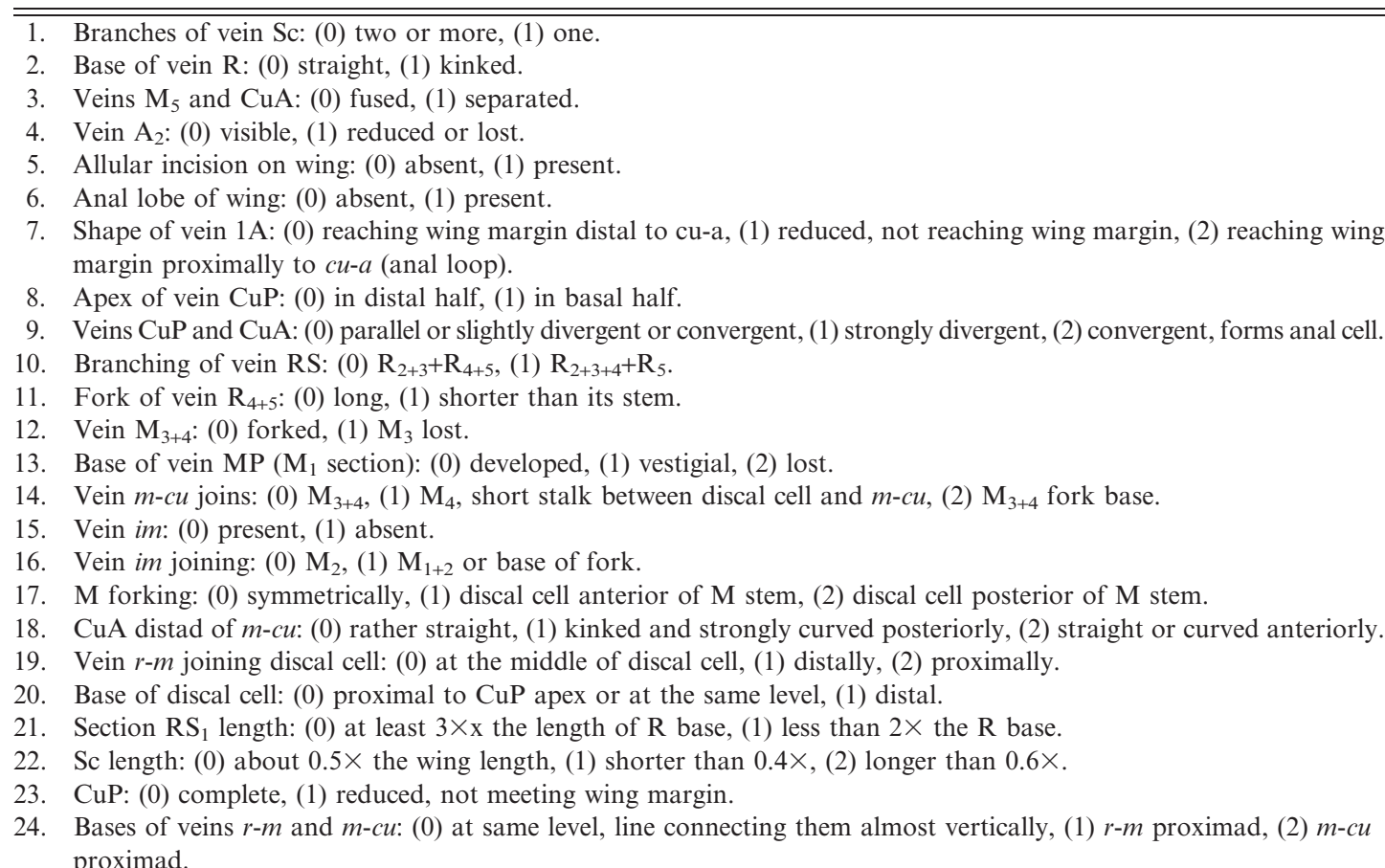

25. Base of vein $\mathrm{R}_{5}$ : (0) oblique or horizontal, (1) vertical, aligned with $r-m$.

26. Tip of vein $R_{3}$ : (0) tips of $R_{1}, R_{3}, R_{4}$ and $R_{5}$ evenly spaced, (1) $R_{3}$ closer to $R_{1}$ rather than $R_{4}$.

27. Relief of vein CuP: (0) convex for entire length, (1) strongly convex distally.

28. Radial cells: (0) same width, (1) cell $\mathrm{R}_{5} / \mathrm{M}_{1}$ wider than $\mathrm{R}_{4} / \mathrm{R}_{5}$, parallel-sided.

29. Vein $\mathrm{R}_{5}$ : (0) normal, (1) continues to the base of wing as a fold.

30. Meron: (0) contiguous with coxa 2, (1) associated with epimeron 2, (2) fused with epm 2 to meropleurite, (3) inconspicuous.

31. Precervical sclerite: (0) absent, (1) present.

32. Laterocervical sclerite: (0) contacts proepisternum, (1) contacts episternal lobe.

33. Laterocervical sclerite: (0) without orifice, (1) with orifice.

34. Mandibles: (0) present and usually better developed or only functional in female, (1) absent.

35. Ocelli: (0) present, (1) absent.

36. Arolium (0): present, (1) replaced with empodium.

37. Last tarsomere of male: (1) normal, not prehensile, (1) capable of folding against penultimate tarsomere.

38. Pedicel: (0) normal, (1) enlarged.

39. Flagellomeres: (0) 10-14, (1) fewer than 8.

40. Parameres: (0) separate, (1) fused to each other.

41. Claws:(0) normal, not folding, (1) fold against distitarsus.

42. Length of setae on flagellomeres: (0) short, (1) as long as flagellomere.

43. Antennal scoids: (0) absent, (1) present.

44. Movemement of gonostyli: (0) horizontal, (1) vertical.

45. Aedeagus: (0) tubular, (1) flattened.

46. Middle legs: (0) normal, (1) shortest of the three pairs.

47. Dorsolateral tubercles on tergite 1: (0) absent, (1) present.

48. MA (arculus): (0) slightly sclerotized, mostly as a crease, (1) as a strong vein.

49. Antepronotum and proepisternum: (0) antepronotum much larger than proepisternum, (1) antepronotum about the size of proepisternum.

50. Basalar pit: (0) absent, (1) present.

51. Postcervical sclerite: (0) normal, (1) produced mesoventrally or absent. 
TABLE 3

(Continued)

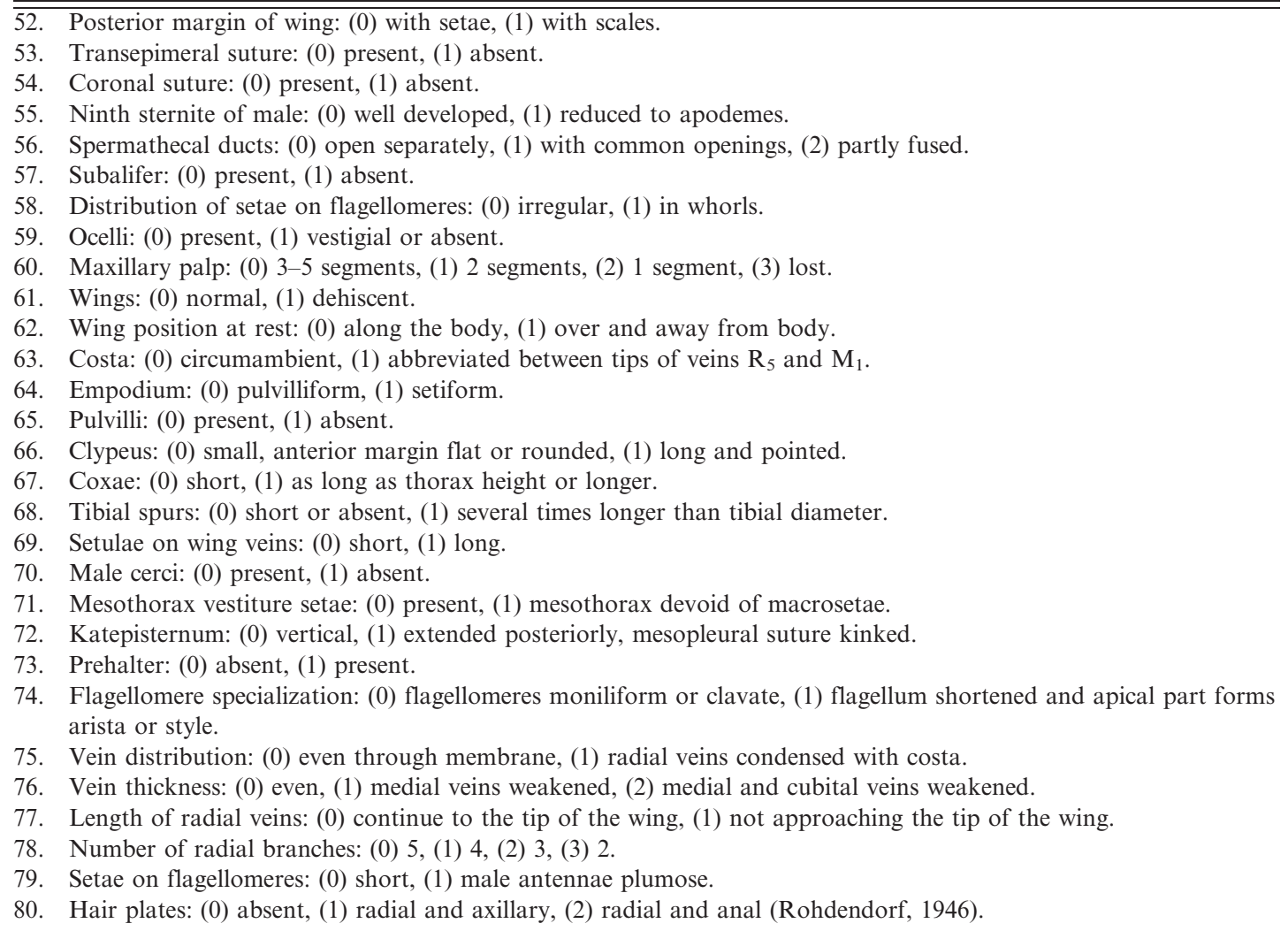

${ }^{\mathrm{a}}$ Character 80 is additive; the rest are nonadditive.

among the Sciaroidea (fungus gnats and allies) have been well treated (Chandler, 2002; Jaschhof, 2001; Jaschhof and Didham, 2002; Blagoderov and Grimaldi, 2004; Hippa and Vilkamaa, 2005; Vilkamaa and Hippa, 2004), and Veriplecia and Virginiptera (Paraxymyiidae: Late Triassic to Cretaceous) appear to be the basal members of the infraorder. Interestingly, the larval biology of Bibionomorpha is unique among nematocerous flies, in that they are largely terrestrial like the large, monophyletic group, the Brachycera (bibionomorphans, however, feed primarily on fungal matter; most basal brachyceran larvae are predaceous). Several studies (i.e., Hennig, 1973), including this one, break with Wood and Borkent (1989) and Oosterbroek and Courtney (1995) in including Anisopodidae in the Bibionomorpha. In fact, it appears that Anisopodidae is probably the sister group to the Brachycera, thus rendering the Bibionomorpha paraphyletic. Anisopodidae is represented in the Triassic by Vymrhyphus, and fossils of the family become more diverse through the later Mesozoic.

Brachycera is the largest and most diverse infraorder in the Diptera, with 110 families and probably over 100,000 described species. It is a definitively monophyletic group as based on, among other features: (1) larval features (obviously not preserved in fossils); (2) reduction of the antennal flagellum to eight or fewer segments (commonly four or fewer), and significant differentiation of the flagellomeres; (3) reduction of the maxillary palp to 1-2 segments; (4) veins $\mathrm{CuA}$ and $\mathrm{CuP}$ (often interpreted as $\mathrm{CuA}_{2}$ and $\mathrm{A}_{1}$ ) with their apices meeting before the wing margin (forming 


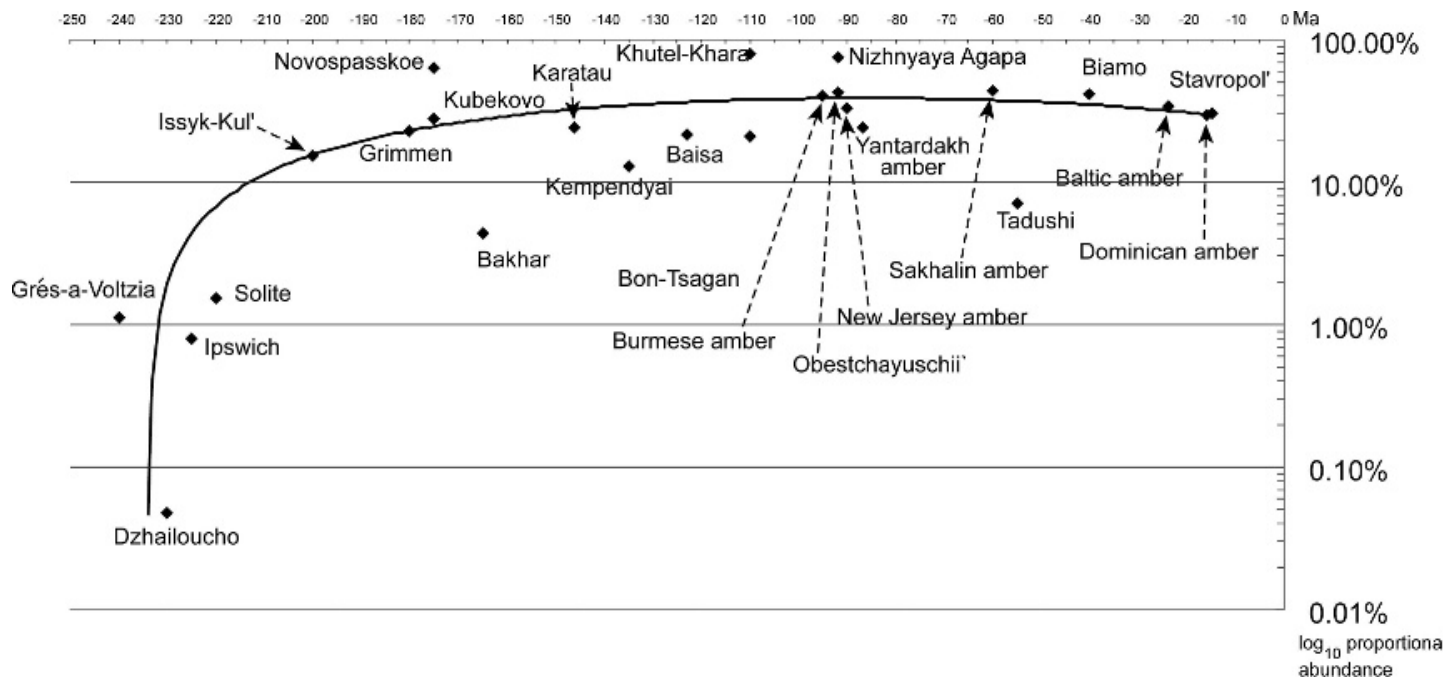

Fig. 14. Relative abundance of Diptera through time, as measured by $\log _{10}$ proportion of Diptera specimens among total number of fossil insect specimens from representative, significant deposits (see table 4). Dipteran abundance asymptotes toward modern levels in the Jurassic because of diversification within infraorders.

a closed cell) or nearly so. Fusion of veins $R_{2}$ and $\mathrm{R}_{3}$ (Hennig, 1973) has been suggested as a fourth defining character, but this is widespread among nematocerous flies. Gallia, from the mid-Triassic of France, is known only from the wing, and it has been classified as a brachyceran (Krzemiński and Krzemińska, 2003). This is based, however, just on wing venation. Our discovery of Prosechamyia from the Solite quarries reveals an additional Triassic fly with convergent $\mathrm{Cu}$ veins, but the antennae (albeit incomplete) are filiform, indicating Prosechamyia is a stem group to true Brachycera. Thus, in lieu of antennal and other structures of Gallia, it is quite possible that it too is a stem group to true brachycerans.

\section{Diptera Abundance And Diversity in THE TRIASSIC}

Our results indicate that stem-group and even some derived members of most major dipteran infraorders existed by the Late Triassic. Diptera, however, were rare in the Triassic, which contrasts starkly with their abundance later in the Mesozoic (fig. 14). For example, in the Triassic deposits at Dzhailoucho (Kyrgyzstan, Central Asia) only
11 fly specimens were found among approximately 20,000 insects; in the Ipswich Series of Australia only four out of 500 (Anderson and Anderson, 1993); and at Grés-a-Voltzia in France only 59 adults out of 5,300 other insects (Krzemiński and Krzemińska, 2003; Marchal-Papier et al., 2000). In the Early Jurassic of Germany-some 40 million years later-Diptera comprised approximately 23\% of all insect specimens, second only to Hemiptera (26\%) (Ansorge, 1996); and in the Late Jurassic of the spectacular insect Concentrat Lagerstätte of Karatau, Kazakhstan, Diptera comprised 24\% (4,791 of 19,879) of all insect specimens (www.palaeoentomolog.ru). By the Early Cretaceous, Diptera comprised approximately $21 \%$ of all insect specimens, such as in the diverse deposits at Baissa, Siberia. These proportions of course reflect biases in the preservation of lacustrine and marine littoral deposits, but the Cretaceous and Tertiary abundance of Diptera is also apparent in amber from those periods, with Diptera (particularly Chironomidae and Ceratopogonidae) typically being the most abundant insect order in amber (e.g., Rasnitsyn and Quicke, 2002; Grimaldi, 2000; Grimaldi et al., 2002). 
TABLE 4

Abundance of Diptera in Major Deposits of Fossil Insects from the Triassic to Neogene (C, compression; A, amber)

\begin{tabular}{|c|c|c|c|c|c|c|}
\hline Locality & Age & $\%$ & Insects $(N)$ & Diptera $(N)$ & Taphonomy & Reference \\
\hline Grés-a-Voltzia & -240 & $1.11 \%$ & 5300 & 59 & $\mathrm{C}$ & Krzemiński, 2003, Papier et al., 2000 \\
\hline Dzhailoucho & -230 & $0.05 \%$ & 23332 & 11 & $\mathrm{C}$ & www.palaeoentomolog.ru \\
\hline Ipswich & -225 & $0.80 \%$ & 500 & 4 & $\mathrm{C}$ & www.palaeoentomolog.ru \\
\hline Solite & -220 & $1.52 \%$ & 3300 & 50 & $\mathrm{C}$ & \\
\hline Issyk-Kul' & -200 & $15.23 \%$ & 2836 & 432 & $\mathrm{C}$ & www.palaeoentomolog.ru \\
\hline Grimmen & -180 & $22.67 \%$ & 1200 & 272 & $\mathrm{C}$ & Ansorge, 1996 \\
\hline Novospasskoe & -175 & $63.26 \%$ & 3100 & 1961 & $\mathrm{C}$ & Kalugina, Kovalev, 1985 \\
\hline Kubekovo & -175 & $28.18 \%$ & 1022 & 288 & $\mathrm{C}$ & www.palaeoentomolog.ru \\
\hline Bakhar & -165 & $4.35 \%$ & 5421 & 236 & $\mathrm{C}$ & www.palaeoentomolog.ru \\
\hline Karatau & -146 & $24.10 \%$ & 19879 & 4791 & $\mathrm{C}$ & www.palaeoentomolog.ru \\
\hline Kempendyai & -135 & $12.94 \%$ & 1182 & 153 & $\mathrm{C}$ & www.palaeoentomolog.ru \\
\hline Baissa & -123 & $21.25 \%$ & 24476 & 5200 & $\mathrm{C}$ & www.palaeoentomolog.ru \\
\hline Bon-Tsagan & -110 & $21.12 \%$ & 9959 & 2103 & $\mathrm{C}$ & www.palaeoentomolog.ru \\
\hline Khutel-Khara & -110 & $80.01 \%$ & 3331 & 2665 & $\mathrm{C}$ & Sontag, 2003 \\
\hline Myanmar & -95 & $40.17 \%$ & 3012 & 1210 & A & Grimaldi et al., 2002 \\
\hline Obestchayuschii & -92 & $42.85 \%$ & 1202 & 515 & $\mathrm{C}$ & www.palaeoentomolog.ru \\
\hline Nizhnyaya Agapa & -92 & $75.10 \%$ & 257 & 193 & A & www.palaeoentomolog.ru \\
\hline New Jersey & -90 & $33.46 \%$ & 1052 & 352 & A & Grimaldi et al., 2000 \\
\hline Yantardakh & -87 & $23.89 \%$ & 854 & 204 & A & www.palaeoentomolog.ru \\
\hline Sakhalin & -60 & $43.41 \%$ & 940 & 408 & A & Zherikhin, 1978 \\
\hline Tadushi & -55 & $7.16 \%$ & 3843 & 275 & $\mathrm{C}$ & www.palaeoentomolog.ru \\
\hline Baltic & -40 & $41.44 \%$ & 7111 & 2947 & A & www.palaeoentomolog.ru \\
\hline Biamo & -24 & $34.17 \%$ & 1718 & 587 & $\mathrm{C}$ & www.palaeoentomolog.ru \\
\hline Dominican Rep. & -16 & $29.65 \%$ & 11814 & 3503 & A & D.Grimaldi, unpubl. \\
\hline Stavropol' & -15 & $30.53 \%$ & 3449 & 1053 & $\mathrm{C}$ & www.palaeoentomolog.ru \\
\hline
\end{tabular}

Diptera from the Triassic of Virginia comprise some $1.5 \%$ of all insect specimens, which is comparable in abundance to other Triassic deposits. Overall, the trend indicates that Diptera were rare in the Triassic, comprising approximately $1 \%$ of all insects and dramatically increasing in abundance in the latest Triassic to earliest Jurassic. By the Late Jurassic $\sim 150 \mathrm{Ma}$ the abundance of Diptera nearly reached that of the Tertiary level, and remained there. By the end of the Triassic flies were global. All Diptera from the locality that has yielded the oldest such specimens, the Grés-a-Voltzia sandstones, belong to extinct and the most basal lineages. Indeed, most basal families (Vladipteridae, Archilimoniidae, Grauvogeliidae, Nadipteridae) occur in Europe and Central Asia. A virtual absence of Diptera in the Australian Triassic is possibly a sampling problem, but insects from the Newcastle Formation in Belmont, Australia are very distinctive among what are otherwise globally uniform Permian insect faunas, so the
Australian Triassic Diptera could reflect regional differences (Ponomarenko and Sukacheva, 1998). There has been little change in the tectonic position of Australia during those $30 \mathrm{Ma}$ between the Triassic and Permian deposits.

In conclusion, the Diptera evolved from a Late Permian Permotipula or Robinjohnialike ancestor that had saprophagous immatures and adults. The exact timing is difficult to discern since the Early Triassic is virtually unknown for insects, but we hypothesize that true, two-winged Diptera originated in the earliest Triassic ca. $245 \mathrm{Ma}$. By $20 \mathrm{Ma}$ after the Permo-Triassic boundary, stem groups and some derived members of the major infraorders had appeared. This would suggest a very rapid diversification or radiation of Diptera in the Early Triassic, which could be the basis for why relationships among infraorders and other higher lineages of living nematocerous flies appear to be so obscure. 


\section{ACKNOWLEDGMENTS}

We thank Tam Nguyen and Steve Thurston for their help in composing the plates; to the former Solite Corporation, particularly John Roberts and C. H. Gover, Richard Familia and Giant Cement, and to Roy Larimer for their help with the excavations; to Tim White for loans of specimens from the Yale Peabody Museum; and to Michael Engel and an anonymous reviewer for their helpful commentary. Lastly, we are indebted to the National Geographic Society and the National Science Foundation (NSF EAR 0106309 to $\mathrm{NF}$ and DG) for funding this project.

\section{REFERENCES}

Amorim, D.S., and D. Grimaldi. 2006. Valeseguyidae, a new family of Diptera in the Scatopsoidea, with a new genus in Cretaceous amber from Myanmar. Systematic Entomology 38: $598-516$.

Amorim, D.S., and S.H.S. Tozoni. 1994. Phylogenetic and biogeographic analysis of the Anisopodoidea (Diptera, Bibionomorpha), with an area cladogram for intercontinental relationships. Revista Brasilensis Entomologia 38: 517-543.

Anderson, J.M., and H.M. Anderson. 1993. Terrestrial flora and fauna of the Gondwana Triassic; 1, Occurrences. In S.G. Lucas and M. Morales (editors), The nonmarine Triassic. Bulletin of the New Mexico Museum of Natural History and Science 3: 3-12.

Ansorge, J. 1994. Tanyderidae and Psychodidae (Insecta: Diptera) from the Lower Jurassic of northeastern Germany. Paläontologische Zeitschrift 68(1/2): 199-210.

Ansorge, J. 1996. Insekten aus dem oberen Lias von Grimmen (Vorpommern, Norddeutschland). Neue Palaeontologische Abhandlungen 2: $1-132+17$ plates.

Axsmith, B., T.N. Thomas, N.C. Fraser, and P.E. Olsen. 1997. An occurrence of the Gondwanan plant Fraxinopsis in the Upper Triassic of eastern North America. Modern Geology 21: 299-308.

Azar, D., A. Nel, M. Solignac, J.-C. Paicheler, and F. Bouchet. 1999. New genera and species of psychodoid flies from the Lower Cretaceous amber of Lebanon. Palaeoontology 42: 1101-1136.

Blagoderov, V.A. 1999. New Bibionomorpha from the Triassic of Australia and Jurassic of Central
Asia with notes on the family Paraxymiidae (Insecta, Diptera). In Proceedings of First Paleoentomological Conference. Bratislava. AMBA projects AM/PFICM98/1.99, pp. 11-15. Blagoderov, V.A., and D.A. Grimaldi. 2004. Fossil Sciaroidea (Diptera) in Cretaceous ambers, exclusive of Cecidimyiidae, Sciaridae, and Keroplatidae. American Museum Novitates 3433: $1-76$.

Chandler, P. 2002. Heterotricha Loew and allied genera (Diptera: Sciaroidea): offshoots of the stem group of Mycetophilidae and/or Sciaridae? Annals de la Societé d'Entomologique de France 38: 101-144.

Courtney, G.W. 1994. Biosystematics of the Nymphomyiidae (Insecta: Diptera): life history, morphology and phylogenetic relationships. Smithsonian Contributions to Zoology 550: $1-41$.

Duckhouse, D.A. 2000. Redescription and reevaluation of the Burmese amber psychodid Eophlebotomus connectens Cockerell and its phylogenetic position (Diptera: Psychodidae). Systematic Entomology 25: 503-509.

Evenhuis, N.L. 1994. Catalogue of the fossil flies of the world (Insecta: Diptera). Leiden: Backhuys, $600 \mathrm{pp}$.

Fraser, N.C., and D.A. Grimaldi. 1999. A significant Late Triassic Lagerstaette from Virginia, U.S.A. Rivista del Museo Civico di Scienze Naturali "Enrico Caffi” (Suppl.) 20: 79-84.

Fraser, N.C., and D.A. Grimaldi. 2003. Late Triassic continental faunal change: new perspectives on Triassic insect diversity as revealed by a locality in the Danville Basin, Virginia, Newark Supergroup. In P.M. LeTourneau and P.E. Olsen (editors), The great rift valleys of Pangea in Eastern North America 2: 192-205. New York: Columbia University Press.

Fraser, N.C., D.A. Grimaldi, P.E. Olsen, and B. Axsmith. 1996. A Triassic Lagerstatte from eastern North America. Nature 380: 615-619.

Friedrich, M., and D. Tautz. 1997. Evolution and phylogeny of the Diptera: a molecular phylogenetic analysis using 28S rDNA sequences. Systematic Biology 46: 674-698.

Gaston, K.J. 1991. The magnitude of global insect species richness. Conservation Biology 5: 283-296.

Goloboff, P. 1999. NONA (No Name), ver. 2. Published by the author. Tucumán, Argentina.

Grimaldi, D.A. (editor), 2000. Studies on fossils in amber, with particular reference to the Cretaceous of New Jersey. Leiden: Backhuys, viii +498 pp.

Grimaldi, D.A., D.S. Amorim, and V.A. Blagoderov. 2003. The Mesozoic family 
Archizelmiridae (Diptera: Insecta). Journal of Paleontology 77: 368-381.

Grimaldi, D., and J. Cumming. 1999. Brachyceran Diptera in Cretaceous ambers and Mesozoic diversification of the Eremoneura. Bulletin of the American Museum of Natural History 239: $1-124$.

Grimaldi, D., and M.S. Engel. 2005. Evolution of the insects. New York: Cambridge University Press, $\mathrm{xv}+755 \mathrm{pp}$.

Grimaldi, D.A., M.S. Engel, and P.C. Nascimbene. 2002. Fossiliferous Cretaceous amber from Myanmar (Burma): its rediscovery, biotic diversity, and paleontological significance. American Museum Novitates 3361: 1-71.

Grimaldi, D., A. Shmakov, and N. Fraser. 2004. Mesozoic thrips and early evolution of the order Thysanoptera (Insecta). Journal of Paleontology 78: 941-952.

Hennig, W. 1954. Flügelgeäder und System der Dipteren unter Berücksitigung der aus dem Mesozoicum beschribenen Fossilien. Beiträge zur Entomologie 4: 345-388.

Hennig, W. 1973. 31. Diptera (Zweiflügler). In J.-G. Helmke, D. Stark and H. Wermuth (editors), Handbuch der Zoologie. IV. Band: Arthropoda-2. Hälfle: Insecta. Zweite Auflage. 2. Teil: Spezielles. Berlin: W. De Gruyter, iii + $337 \mathrm{pp}$.

Hippa, H., and P. Vilkamaa. 2005. The genus Sciarotricha gen. n. (Sciaridae) and the phylogeny of recent and fossil Sciaroidea (Diptera). Insect Systematics and Evolution 36: 121-144.

Hong, Y.-C., and X.-R. Gou. 2003. Two new middle Triassic genera and species of Mesopanorpodidae from Shaanxi (Insecta, Mecoptera). Acta Zootaxonomica Sinica 28: 716-720.

Jaschhof, M. 1998. Revision der "Lestrimiinae" (Diptera, Cecidomyiidae) der Holarktis. Studia Dipterologica, Supplement 4: 1-552.

Jaschhof, M., and R.K. Didham. 2002. Rangomaramidae fam. nov. From New Zealand and implications for the phylogeny of the Sciaroidea (Diptera: Bibionomorpha). Studia Dipterologica Supplement 11: 1-59.

Kalugina, N.S., and V.G. Kovalev. 1985. Diptera (Insecta) of the Jurassic of Siberia. Moskow: Nauka, 197 pp. [In Russian]

Kent, D.V., P.E. Olsen, and W.K. White. 1995. Late Triassic-earliest Jurassic geomagnetic polarity sequence and paleolatitudes from drill cores in the Newark rift basin, eastern North America. Journal of Geophysical Research. B. Solid Earth and Planets 100: 14,965-14,998.

Kovalev, V.G. 1983. A new family of the Diptera from the Triassic deposits of Australia and its presumable descendants (Diptera, Crosa- phididae fam. n., Mycetobiidae). Entomologicheskoe Obozrenie 62: 800-805. [In Russian]

Krzemiński, W. 1992. Triassic and Lower Jurassic stage of Diptera evolution. Mitteilungen der Schweizerischen Entomologichen Gesellschaft 65: 39-59.

Krzemiński, W. 2004. Yalea, a replacement name for Yala Krzeminski, 1992 (Diptera: Procramptonomyiidae). Acta Zoologica Cracoviensia 47: 229.

Krzemiński, W., and N. Evenhuis. 2000. Review of Diptera paleontological record. In L. Papp and B. Davis (editors), Contributions to manual of Palearctic Diptera. Vol. 1: 535-564. Budapest: Science Herald.

Krzemiński, W., and E. Jarzembowski. 1999. Anne triassica, n.sp., the oldest representative of Chironomidae. Polskie Pismo Entomologiczne 68: 445-449.

Krzemiński, W., and E. Krzemińska. 2003. Triassic Diptera: descriptions, revisions and phylogenetic relations. Acta Zoologica Cracoviensia (suppl.) 46: 153-184.

Krzemiński, W., E. Krzemińska, and F. Papier. 1994. Grauvogelia arzvilleriana sp. n.- the oldest Diptera species (Lower/Middle Triassic of France). Polskie Pismo Entomologiczne 65: 267-274.

LeTourneau, P.M., and P.E. Olsen (editors). 2003. The great rift valleys of Pangea in Eastern North America, vols. 1, 2. New York: Columbia University Press.

Lucas, S.G., and P. Huber. 2003. Vertebrate biostratigraphy and biochronology of the nonmarine Late Triassic. In P.M. LeTourneau and P.E. Olsen (editors), The great rift valleys of Pangea in Eastern North America 2: 143-191. New York: Columbia University Press.

Lukashevich, E.D., and M.B. Mostovski. 2003. Hematophagous insects in the fossil record. Paleontologicheskii Zhurnal 2003: 48-56.

Marchal-Papier, F., A. Nel, and L. GrauvogelStamm. 2000. Nouveaux orthopteres (Ensifera, Insecta) du Trias des Vosges (France). Acta Geologica Hispanica 35: 5-18.

Martins-Neto, R.G., O.F. Gallego, and R.N. Melchor. 2003. The Triassic insect fauna from South America (Argentina, Brazil and Chile): a checklist (except Blattoptera and Coleoptera) and description of new taxa. Acta Zoologica Cracoviensia (suppl.) 46: 229-256.

McAlpine, J.F. 1981. Morphology and terminology - adults. In J.F. McAlpine et al. (editors). Manual of Nearctic Diptera. Agriculture Canada Monograph (27) 1: 9-64.

Michelsen, V. 1996. Neodiptera: new insights into the adult morphology and higher level phylog- 
eny of Diptera (Insecta). Zoological Journal of the Linnean Society 117: 71-102.

Miller, B.R., M.B. Crabtree, and H.M. Savage. 1997. Phylogenetic relationships of the Culicomorpha inferred from the $18 \mathrm{~S}$ and $5.8 \mathrm{~S}$ ribosomal DNA sequences (Diptera: Nematocera). Insect Molecular Biology 6: 105-114.

Olsen, P. 1986. A 40-million-year lake record of early Mesozoic orbital climatic forcing. Science 234: 842-848.

Olsen, P.E., C.L. Remington, B. Cornet, and K.S. Thompson. 1978. Cyclic change in Late Triassic acustrine communities. Science 201: 729-733.

Oosterbroek, P., and G. Courtney. 1995. Phylogeny of the nematocerous families of Diptera (Insecta). Zoological Journal of the Linnean Society 115: 267-311.

Pawlowski, J., R. Szadziewski, D. Kmieciak, J. Fahrni, and G. Bittar. 1997. Phylogeny of the infraorder Culicomorpha (Diptera: Nematocera) based on 28S RNA gene sequences. Systematic Entomology 21: 167-178.

Ponomarenko, A.G., and I.D. Sukacheva. 1998. [Insects]. In V.R. Lozovsky and N.K. Esaulova, Permian-Triassic boundary in the continental series of Eastern Europe: 96-106. Moscow: GEOS.

Rasnitsyn, A.P. and D.L.J. Quicke (editors) History of insects. Dordrecht: Kluwer Academic Publishers, xii + 1-517 pp.

Shcherbakov, D., E. Lukashevich, and V. Blagoderov. 1995. Triassic fossils and initial radiation of Diptera. Dipterological Research 6: 75-115.
Sinclair, B. 1992. A phylogenetic interpretation of the Brachycera (Diptera) based on the larval mandible and associated mouthpart structures. Entomologica scandinavaca 24: 407-432.

Vilkamaa, P., and H. Hippa. 2004. The genus Xenosciara gen. N. and the phylogeny of the Sciaridae (Diptera). Zootaxa 699: 1-24.

Willmann, R. 1989a. Evolution und phylogenetisches System der Mecoptera (Insecta: Holometabola). Abhandlungen der Senckenbergischen Naturforschenden Gesellschaft 544: $1-153$.

Willmann, R. 1989b. Rediscovered: Permotipula patricia, the oldest known fly. Naturwissenschaften 76: 375-377.

Witte, W.K., D.V. Kent, and P. Olsen. 1991. Magnetostratigraphy and paleomagnetic poles from Late Triassic-earliest Jurassic strata of the Newark Basin. Bulletin of the Geological Society of America 103: 1648-1662.

Wood, D.M., and A. Borkent. 1989. Phylogeny and classification of the Nematocera. In J.F. McAlpine and D.M. Wood (editors), Manual of Nearctic Diptera. Agriculture Canada Monograph (32) 3: 1333-1370.

Woodley, N.E. 1989. Phylogeny and classification of the "orthorrhaphous" Brachycera. In J.F. McAlpine and D.M. Wood (editors), Manual of Nearctic Diptera. Agriculture Canada Monograph (32) 3: 1371-1396.

Zherikhin, V.V. 1978. Development and changes of the Cretaceous and Caenozoic faunistic assemblages (Tracheata and Chelicerata)]. Trudy Paleontologicheskogo Instituta Akademii Nauk USSR 165: 1-198. Moscow: Nauka. [In Russian] 
Complete lists of all issues of the Novitates and the Bulletin are available at World Wide Web site http://library.amnh.org/pubs. Inquire about ordering printed copies via e-mail from scipubs@amnh.org or via standard mail from: American Museum of Natural History, Library-Scientific Publications, Central Park West at 79th St., New York, NY 10024. TEL: (212) 769-5545. FAX: (212) 769-5009.

@ This paper meets the requirements of ANSI/NISO Z39.48-1992 (Permanence of Paper). 